\title{
Irrigation water management for sustainable cultivation of date palm
}

\author{
Latifa Dhaouadi ${ }^{1,2} \cdot$ Houda Besser $^{3} \cdot$ Nissaf Karbout ${ }^{4} \cdot$ Abdulrasoul Al-Omran $^{5} \cdot$ Fatma Wassar $^{6}$. \\ Mohamed Shahata Wahba ${ }^{7} \cdot \mathrm{Kang}$ Yaohu $^{7} \cdot$ Younes $\mathrm{Hamed}^{8}$
}

Received: 23 February 2021 / Accepted: 27 September 2021 / Published online: 8 October 2021

(c) The Author(s) 2021

\begin{abstract}
Given the aesthetic, cultural, ecological, and economic value of the date agro-system in Southwestern Tunisia, different management and conservation strategies have been warrantee to optimize land productivity sustainably. However, the inefficiency of the adopted management actions resulted in a continuous loss of soil fertility and decreasing fruit quality. Thus, the present paper attempts to evaluate accurately the evolution of the principal factors influencing date palm production and agricultural activities sustainability in the region. Integrated approaches of various irrigation water quality indices and geostatistical analysis coupled with field investigation and farming survey were applied to evaluate the evolution of key parameters influencing the development of date palm sustainably. The obtained results of the research indicate that the progressive land degradation is due to the effects of poorquality of water used for irrigation (EC between 674.4 and $5450 \mu \mathrm{s} /$ $\mathrm{cm}$, SAR exceeding locally 20 and about $80 \%$ of all the samples waters are of undoubtful quality according to the calculated indices), inappropriate irrigation scheduling (physiologic drought that might reach 3 months), traditional basin irrigation technique (decreasing of yield productivity, locally of $0.23,0.23$ and $0.25 \mathrm{~kg} \mathrm{~m}^{-3}$ ), an indigenous knowledge (sandy amendment, biologic compost, gravity improved irrigation.....). Also climate variability has leaded to furthermore degradation of crop quality. The degradation of date palm culture will be a great challenge for environmental conservation, food security and socio-economic values of the region unless a reasonable management take place, a flexible strategy based on indigenous knowledge of landowner, and scientific-based outlines with climate risks evaluation. The present paper might be useful to policy makers as a multi-disciplinary research covering most of the important aspects of date palm production.
\end{abstract}

Keywords Date palm $\cdot$ Water quality $\cdot$ Economic security $\cdot$ Agronomic analysis $\cdot$ Irrigation $\cdot$ Arid lands

$\begin{array}{ll}\text { Abbreviations } \\ \text { EC } & \text { Electrical conductivity } \\ \text { SAR } & \text { Sodium adsorption ratio } \\ \text { KR } & \text { Kelly's ratio } \\ \text { PI } & \text { Permeability index } \\ \text { MH } & \text { Magnesium hazard } \\ \text { TH } & \text { Total hardness }\end{array}$

Latifa Dhaouadi

latifa_hydro@yahoo.fr

1 Regional Center for Research in Oasis Agriculture, Cartage University, Km1 Route de Tozeur CP: 2260 Deguache, Ariana, Tunisia

2 Water Sciences and Technologies Laboratory, National Institute of Agronomy of Tunisia, Carthage University, Tunis, Tunisia

3 Research Unit of Geo-Systems, Geo-Resources and Geo-Environments (UR3G), Department of Earth Sciences, Faculty of Sciences of Gabes, City Campus Erriadh-Zirig, 6072 Gabes, Tunisia
SSP Soluble sodium percent

ESP Exchangeable sodium percentage

CI Continental intercalaire

CT Complex terminal

SASS Système Aquifère du Sahara Septentrional

TDS Total dissolved solids

WQI Water quality index
4 Institute of Arid Regions, Medenine, Tunisia

5 Soil Science Department, King Saud University, Riyadh, Saudi Arabia

6 Higher Institute of Sciences and Techniques of Water of Gabes, Gabes, Tunisia

7 Institute of Geographic Sciences and Natural Resources Research, Chinese Academy of Sciences, University of Chinese Academy of Sciences, Huairou, China

8 Department of Earth Sciences, Faculty of Sciences of Gafsa, Gafsa, Tunisia 


$\begin{array}{ll}\text { HCA } & \text { Hierarchical cluster analysis } \\ \text { CA } & \text { Correlation analysis } \\ \text { PCA } & \text { Principal component analysis } \\ \text { PDES } & \text { Plan Directeur des Eaux du Sud } \\ \text { APIOS } & \begin{array}{l}\text { Amelioration des Perimètres Irrigués dans Les } \\ \text { Oasis du Sud }\end{array} \\ \text { CES } & \begin{array}{l}\text { Conservation des Eaux et du Sol }\end{array}\end{array}$

\section{Introduction}

In hot and dry areas, where agriculture is the major land-use activity, the continuous exploitation of natural resources and the expanding agro-based economies induce several environmental problems threatening the sustainability of this production. The complex inter-linkages water-food-economy defines a huge challenge amplified with climate change impacts (Abdelhadi et al. 2020; Mishra et al. 2012; 2021; Haritash et al. 2016; Kumar et al. 2020). Flooding irrigation, water scarcity associated with primary and secondary salinization of agricultural lands limits the utilization of these resources for irrigation rather than for salt-tolerant plants (Al-Taani et al. 2013; Bataynah et al. 2015; Al-Muaini et al. 2017 , 2018) namely date palm production.

Indeed, date palm cultivation represents not only key economic activities in semi-arid and arid agro-based areas where agriculture relies especially on the most salt-tolerant plants for a permanent crop, but it has an integral role in the religious life, in the daily culture, and the hieratical valorization of these areas (Mishra et al. 2012, 2021; Haritash et al. 2016; Kumar et al. 2020). Date palm is one of the most salttolerant fruit trees that can withstand harsh desert climate conditions. Previous works indicated that the average daily water use of date trees is about 7 to $14.6 \mathrm{~mm}$ and 2 to $4 \mathrm{~mm}$ during summer and winter periods, respectively (Mohamed et al. 2005; FAO 2007; Dewidar et al. 2015). These trees can be short-lived about 100 years (Ali 2010) and they start up to the production top after 10 to 15 years of cultivation, depending on environmental conditions and agricultural practices (Ali 2010).

Undoubtedly, the resilience of date palm to drought conditions through the prolonged period guarantees that these trees may survive, grow, and bear fruits but to flourish and produce high-quality products, some requirements are needed to be carefully estimated. Thus, this agro-industry reveals great concern in the Arab world for irrigation water management with practical guidelines development and adequate technical capacity. Pilot studies, workshops, collaboration with national and international organizations to improve researches on crop water management and sustainable date palm production. Indeed, date palm adaptation to arid and salt conditions has led to misunderstandings about the real requirements of this type for optimal production (Dhaouadi et al. 2017, 2020; 2021; Al-Omran et al. 2018).

In Southern Tunisia where agriculture-based economic development has actively flourishing supporting a huge pat and social growth providing important energy food security, the progressive continuous degradation of the oasis agro-system warrants immediate conservation remediation strategies. To overcome all these issues to ensure efficient transit management $\mathrm{z}$ reexamination of different key factors influencing the sustainable economic diversity of the area is required. Thus, this paper investigates, via coupled hydrochemical, geochemical, and agronomic analysis with socioeconomic and environmental examination to gain insights about the multi-components cycles of future-proofing optimizing water usage, and improving tools of agricultural management.

\section{Data collection}

\section{Site description}

The study area, situated in Southwestern Tunisia (Fig. 1), is characterized by the desert landscapes of sandy dunes and salt lakes with hyper-arid climate identified by hot long dry summers (Temperature that may exceed $55^{\circ} \mathrm{C}$ ), scare annual precipitation less than $100 \mathrm{~mm}$, and no perennial surface water resources. Evaporation can reach $2000 \mathrm{~mm}_{\text {year }}{ }^{-1}$. In the spring and summer seasons, the strong hot winds of sirocco blow carrying sands from the desert into the oasis (Sghaier 2010).

These difficult conditions have led to increased exploitation of groundwater systems to meet agricultural water supply. The groundwater supplying in southern Tunisia comes from two multi-layered aquifers (the Complex Terminal logging in Upper Cretaceous-Early Tertiary heterogeneous formations and the Continental Intercalative hosted in the Lower Cretaceous continental megastructure) forming one of the largest aquifer systems in the world of the aquifer system of Northern Sahara. The shallow Plio-Quaternary aquifer, given low potential and increasing salinity, is used only during water shortage periods (Edmunds et al. 1997, 2003; Hamed et al. 2013). Locally, under the irrigated fields, some small new-formed aquifers were recognized by an excess of irrigation water and drainage runoff (Dhaouadi et al. 2015; Hamed 2015; Besser et al. 2017).

The sustainable development of oases depends on several influencing factors that should be carefully evaluated at the field level with the inter-relation of physical characteristics of agricultural lands and crop types. The irrigation of saline soils requires basic management control related to timing and amount of irrigation, which strongly affect plant physiologic characteristics and yield loss 


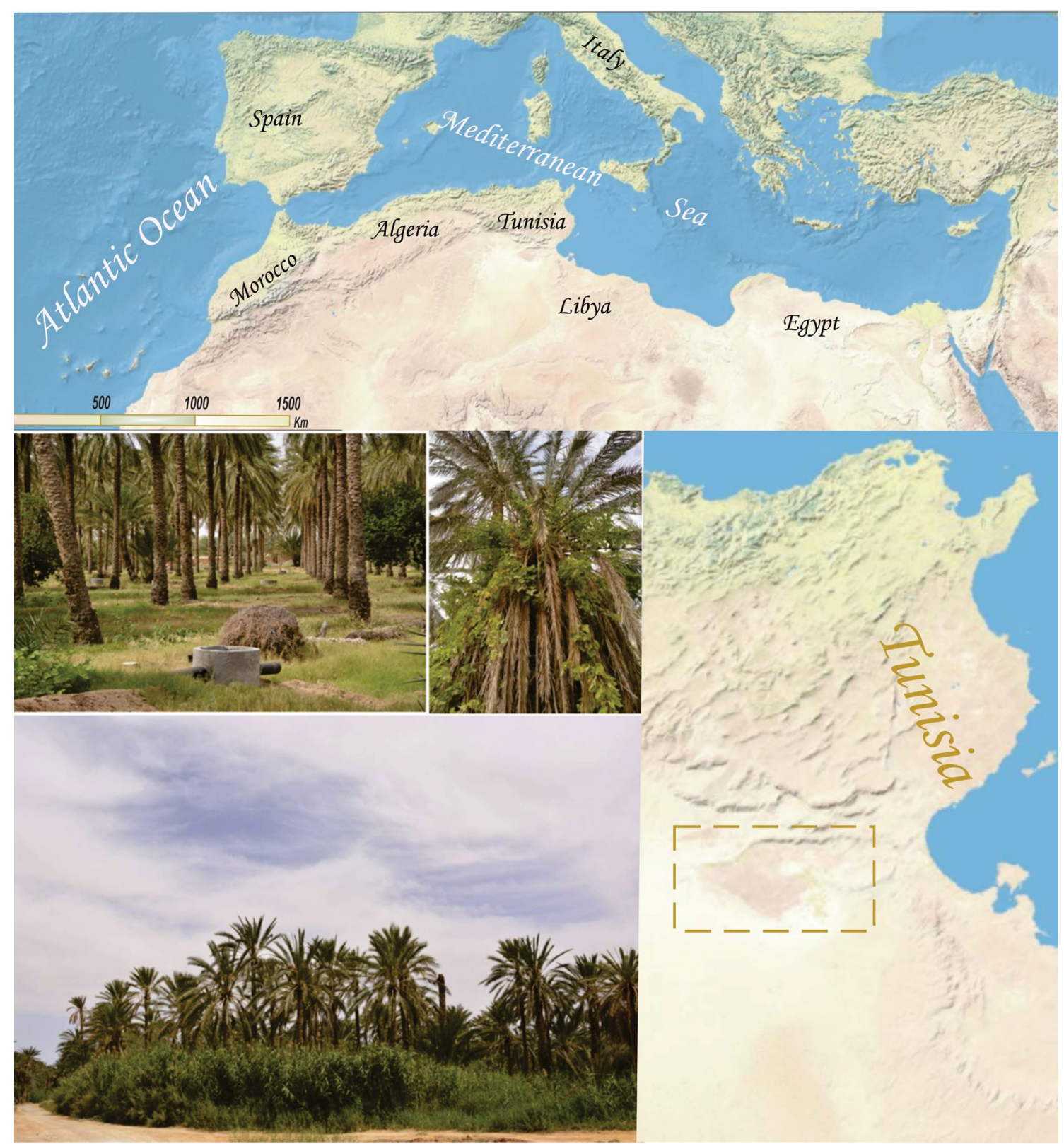

Fig. 1 Date agro-systems of the study area

(Alhammadi and Al Shrouf 2013). Southwestern Tunisia undergoes rapid expansion of agricultural activities depending exclusively on groundwater resources, which results in rapid failing down of water table exceeding the replenishment of these aquifers (exploitation rate of about $176.7 \%$ and $78.23 \%$ in Kebili and Tozeur regions (CRDA 2018). The exploitation of these non-renewable resources under present-day conditions defines serious challenges of the availability of water resources in both terms' quantity and quality for sustainable supply in the study area. The evolution of the abstraction from these reservoirs, the unique resources available to meet water supply make these systems particularly susceptible to degradation and pollution.

\section{Methodology}

\section{Water quality assessment}

Water sampling depends on research questions and outcomes regarding the study area scale. Thus, for the evaluation of water quality suitability for irrigation purposes in the current study sampling campaigns were carried for some water wells distributed across the Kebili field to make evidence 
of spatial variability of water composition which may give more reliable and accurate information spatio-temporal patterns controlling water quality and different environmental related issues.

Twenty-eight functional boreholes within the Nefzaoua region and its environs were sampled. The sampled CI water wells are deep with depths ranging from 485 to $2580 \mathrm{~m}$. These waters are mainly irrigation purposes of oases and greenhouses. Few atmospheric water-cooling systems are available to reduce the temperature of these thermal waters. Some field measurements were evaluated using portable multi-parameter instruments. Then, the collected samples were stored in sterile plastic bottles of $1.5 \mathrm{~L}$ and they were transported to the Laboratory of ISSTEG-Gabe where the analyses of the dissolved chemical elements were performed using the standard laboratory techniques namely titration, volumetric methods, mass-spectroscopy. Duplicate analyzes were used to test the precision and the accuracy of the obtained results.

The good samples were collected and analyzed for electrical conductivity, $\mathrm{pH}$, cations, anions, and $\mathrm{B}$. The EC was determined using EC-meter $\left(\mathrm{dSm}^{-1}\right.$ at $25^{\circ} \mathrm{C}$ ) (Test kit Model 1500_20 Cole and Parmer). The $\mathrm{pH}$ was measured using a pHmeter ( $\mathrm{pH}$ meter-CG 817). The soluble cations $\left(\mathrm{Ca}^{2+}\right.$ and $\left.\mathrm{Mg}^{2+}\right)$ were determined by the ethylene diamine tetraacetic acid (EDTA) titration method. The soluble $\mathrm{Na}^{+}$ and $\mathrm{K}^{+}$were determined using flame photometer apparatus (Corning 400). The $\mathrm{CO}_{3}{ }^{=}$and $\mathrm{HCO}_{3}{ }^{-}$anions were determined by sulfuric acid $\left(\mathrm{H}_{2} \mathrm{SO}_{4}\right)$ titration method, whereas the $\mathrm{Cl}^{-}$was determined by titration with silver nitrate $\left(\mathrm{AgNO}_{3}\right)$ (APHA 1998). The sulfate $\left(\mathrm{SO}_{4}{ }^{2-}\right)$ was determined in suspended solution using a turbiditymeter, and the nitrate $\left(\mathrm{NO}_{3}{ }^{-}\right)$was determined by the phenolsulfonic acid method (APHA 1998). The B was determined using the azomethineH method (Bingham 1982).

\section{Accuracy of collected data}

The accuracy of the collected results was verifying by calculating the errors of ion balance; then, standard solutions as blanks are usually run to check for possible errors in the analysis steps. The percentage of error in the data is calculated using the following Eq. (1) (Appelo and Postma 1996):

The error of ion balance $=\frac{\sum \text { cations }-\sum \text { anions }}{\sum \text { cations }+\sum \text { anions }} * 100$

An error of up to \pm 2 percentage is acceptable, while any sample had error difference than this band should be taken for repeating the analysis. About, $98 \%$ of the samples were inside this range. This means that the resultant data quality is sufficient enough for calculation of (WQI) and determining the type of water to conclude water quality.

\section{Calculation of water quality index}

The calculation of WQI for estimating the effect of physical and anthropogenic actions is based on numerous key elements in the chemistry of groundwater on the collected data. To estimate the WQI, the weight has been assigned for each of the physic-chemical elements according to the elements based on the relative importance in the overall quality of water for drinking purposes. The weight values range between one and five. The maximum weight of 5 has been assigned for $\mathrm{NO}_{3}{ }^{-}$like the importance of this element in the region, 4 for TDS, $\mathrm{pH}, \mathrm{EC}, \mathrm{SO}_{4}{ }^{2-}, 3$ for $\mathrm{HCO}_{3}{ }^{-}, \mathrm{Cl}^{-}$, and 1 for $\mathrm{Ca}^{2+}, \mathrm{Na}^{+}, \mathrm{K}^{+}$, and $\mathrm{Mg}^{2+}$ (Ramakrishnalah et al. 2009; Lateef 2011; Al-Hadithi 2012; Al-Omran 2013). The relative weight is calculated by using the equations given in the table.

\section{Hydrochemical characterization}

The groundwater samples' hydrochemical categorization was estimated by using the major cations and anions. The obtained data are aggregated on the Piper, and Durov diagrams using Geochemistry Software AquaChem 2014.2 to classify the types of water. United States salinity laboratory (Richards 1954) and Gibbs (Gibbs 1970) diagrams were also used in this research. Moreover, salinity hazard, sodium adsorption ratio (SAR), sodium percent (Na $\%$ ), Kelly's ratio (KR), and permeability index (PI) were estimated to investigate the suitability of groundwater for irrigation purposes.

\section{Oasis workshop/field investigation}

The workshop and the field survey were carried to carefully evaluate the current status of date palm production through an accurate collection of data relative to agronomic analysis, irrigation engineering, and economic security to achieve the anticipated objectives related to proper interpretation of the different implemented land projects and the promising data land-use alternatives. A detailed discussion with landowners was carried to highlight the socio-economic implications of the currently adopted management plans and the required development works in their ways the land survey accomplished in different localities from the Kebili region, encompassed various attributes of soil quality, land use, farming system, institutional control, socio-economic benefit. That may directly or (and) indirectly influence the performance of the agricultural system. The data contained in such a wisely prepared survey is of paramount importance to select the appropriate requirements for sustainable land development and prescribing irrigation and drainage promising practices. 


\section{Data interpretation}

The assessment of oasis management issues and inter-links between different influencing factors is required to fulfill the growing demand and to optimize the utilization of natural resources sustainably, through a hierarchical evaluation of key parameters influence and variability impact on oasis development. In the current study, the adoption of articulated classifications based on irrigation quality limits may represent a helpful tool for decision-making process and reduce management costs.

In the current study, the interpretation of the collected data hinges starts with an evaluation of the information obtained during field investigation about the farming system, indigenous knowledge, and irrigation practices. The results obtained from geochemical analyses of water samples were used to classify usability of these resources according to their effects on crop yield and soil fertility (agronomic quality indicators), socio-economic (socio-economic indicators), and irrigation systems (management quality indicators). The collected data were analyzed using the GIS platform and Global mapper for mapping and spatial visualization of the investigated parameters. Geochemical data were treated with Diagramme, Phreeq C, and SPSS software for statistical analysis using Pearson correlation, principal components, and hierarchical analyses.

\section{Results and discussion}

\section{Agronomic quality assessment}

To optimize palm production, some requirements are important, carefully identified by previous works but they still reveal, often, local modifications according to some specific conditions of plant growth. Among these requirements:

\section{Climate conditions}

The climate requirements for sustainable production of these thermopile species have been carefully evaluated and systematically reviewed by several authors namely Zaid and De Wet (2002), Carr (2012), and Dhaouadi et al. (2020). These works indicated that the date palm ecosystem of an arid nature is characterized by high temperature, low humidity, ample sunshine, low rainfall amount, and dust and sand storm (Zaid and De Wet 2002; Carr (2012). The effects of the aforementioned factors on trees growth, productivity, or fruit quality should not be evaluated separately. Climate impacts are, consequently, determined via the great spatial variability of different date characteristics across the productive countries and at a small scale within the same province. For southern Tunisia, Dhaouadi et al. (2020) indicated that the resilience of the palm plantation is reduced and a continuous abandonment of agricultural land is observed annually (Fig. 2). Concerning climate requirements, the study area is characterized by elevated temperature and low air humidity. The scarce rainfall and the important insulation period increase site suitability to important productivity. However, during the last years, climate variability was characterized by frequent extreme events and frequent dust and sandy days. In fact, according to the obtained data from four local meteorological stations in the study area the average rainfall of $100 \mathrm{~mm}$ per year has decreased to less than $55 \mathrm{~mm}$ from 2017 to 2020 with a mean of air humidity of $58 \%$, mean evapotranspiration of $2740 \mathrm{~mm}$, and about 100 to 120 sandy days over the last four years. These indices may adversely impact maturation, diseases, and germination and adhere to data fruit. First, according to FAO (2007), an increase of palm plantations may be attested for increasing salinization of irrigation water above recommended values for long-term uses. The amplitude and the extent of this issue are closely related to the appropriateness and the effectiveness of the other farming management processes. Second, according to the work of the management of strategies adopted by the local owners and governmental institutions create the so-called oases micro-climate that has various advantages related mainly to the conservation of humidity rate, in contrast, with the desert landscape features that may be helpful for the growth of other cultivated types in the oases. This micro-climate presents, in addition, some disadvantages that change correspondingly with inappropriate management to huge constraints for healthy palm development. These issues are related principally to the appearance of some diseases on the most important palm type 'Deglet Ennour.' These diseases affect furthermore, other date types which currently show a great reduction of type diversity in southern Tunisia.

\section{Physio-chemical conditions}

The suitability of water resources for agricultural activities depends on several parameters evaluating the likely consequences of this irrigation on soil fertility and crop growth namely that controls metal transfer, biological functions, and chemical element leachability (Singh et al. 2000; Zhang et al. 2015). The sampled waters have $\mathrm{pH}$ values ranging from 7.49 and 8.10 which enhances the agricultural soil to good buffering capacity for stabilizing dissolved elements and regulates nutrient conditions (Bortolini 2018). The measured concentrations of the major cations vary from 103.9-1199 mg/L, 0.-62.95, 67.9-, and 11.17-247 for Na, $\mathrm{K}, \mathrm{Ca}$, and $\mathrm{Mg}$, respectively. These values are largely above the recommended concentrations for agricultural purposes mentioned by Ayers and Westcot (1985) Duncan (2000) (4, $2.982,7$ and $0.8 \mathrm{meq} / \mathrm{L}$ ). Similarly, the anion concentrations ranging from indicate high mineralized waters exceeding 

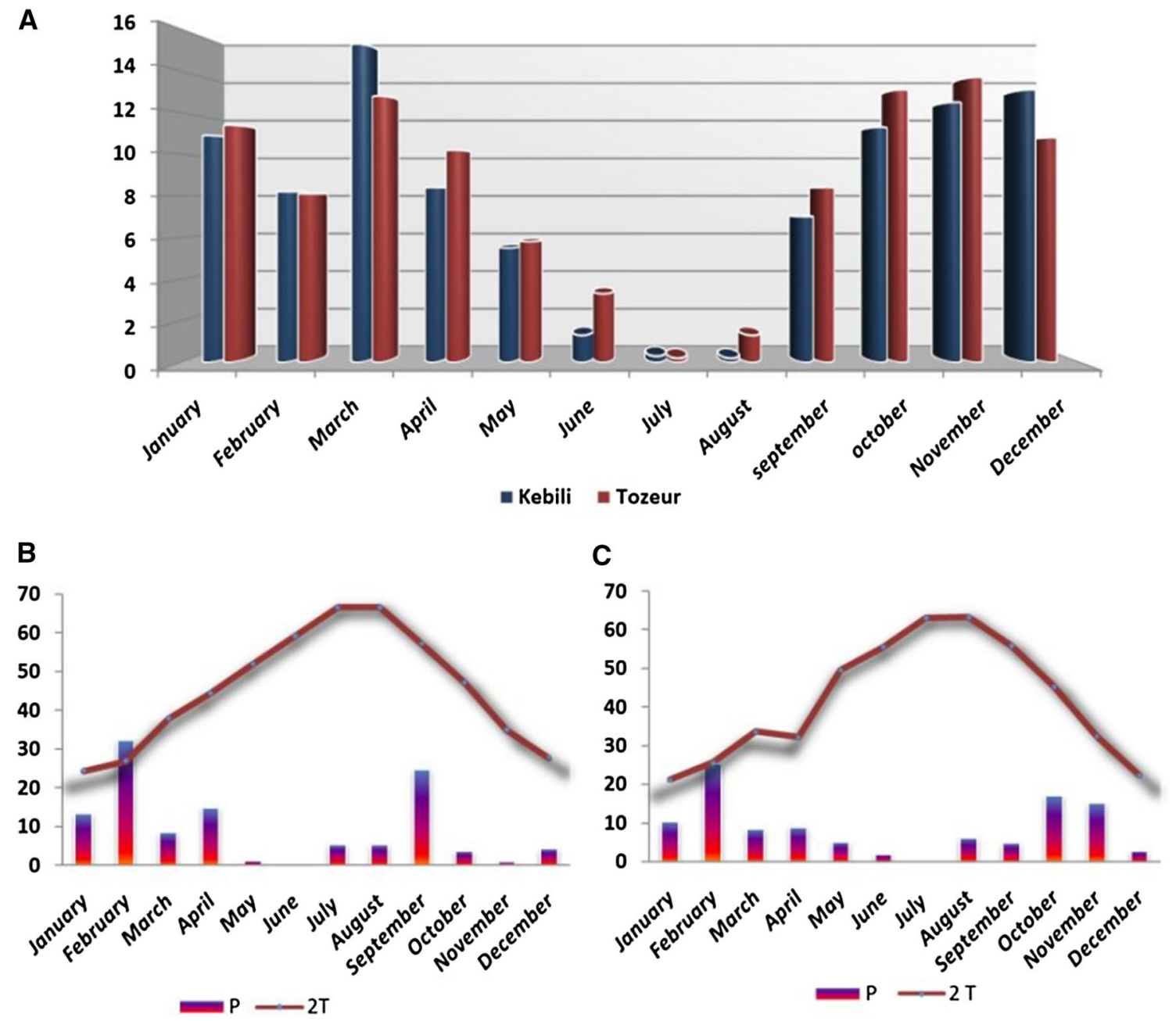

Fig. 2 Climate data of the study area

the permissible contents of $0.1,5.5,7,17$, and 10 for $\mathrm{CO}_{3}$, $\mathrm{HCO}_{3}, \mathrm{Cl}, \mathrm{NO}_{3}$, and $\mathrm{SO}_{4}$, respectively. Based on Styufzand's (Stuyfzand 1986) classification, the chemical composition of the sampled waters suggests high saline to brackish waters with chloride dominance exhibiting permissible to doubtful quality to be used in irrigation. The long-term use of these waters should be associated with appropriate farming practices and an efficient drainage system to impede salt accumulation and pores sealing.

Salinity hazard: The risk of saline conditions development is evaluated in this study, by EC and TDS which differ from $674.4 \mathrm{To} 5450 \mathrm{~g} / \mathrm{L}$ and from 2870 to 8530 , respectively. The measured data indicate that the sampled waters reveal high salinity hazard with values exceeding the maximum acceptable limits for long- and short-term irrigation according to water classification based on (FAO (2007) and USSL (1954) thresholds. This quality is, furthermore, evaluated via water type using Longenecker and Lyerly (1994) chart. In fact, according to the distribution of the analyzed samples on the Piper diagram, the hydrochemical facies of the waters are dominated by sodium, chloride, and calcium indicating moderate to large salt accumulation in the irrigated soils. Moreover, the calculated values of potential salinity exceed, twice or three times the limits for irrigation for the majority of the samples (Table 1). Indeed, increasing salinity adversely affects agricultural lands and reduces their productivity via reduction of soil aeration, water infiltration which increases osmotic pressure and inhibits plants to take nutrients resulting in progressive physiologic droughts especially for saltsensitive crops (Ayers and Westcot 1985; Besser et al. 2017).

Sodium hazard: the distribution of SAR, ESP, and Na is illustrated by Fig. 3 Wilcox and Riverside diagrams illustrate the increasing risks of alkalinization and soil infertility due to dispersion of aggregates, reduction of soil aeration, and physiological drought (Mishra et al. 2012, 2021; Kumar et al. 2020). These waters may induce for long-term uses important impact even for the most tolerant plant to dry conditions, unless appropriate leaching 


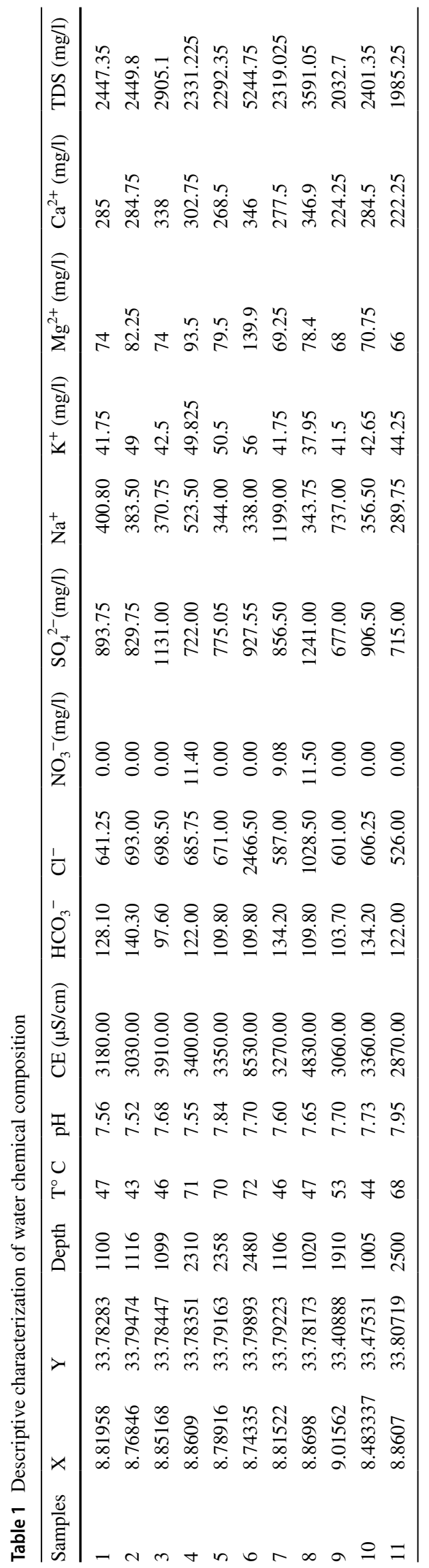

is applied and restrict drainage conditions are controlled regarding the high SSP and ESP values (Figs. 3, 4, and 5). Sodium is one of the most essential elements for safe plant growth, while high sodium content brings harmful impacts on soil proprieties namely particles dispersion, aggregates instability, soil structure deterioration, soil pores sealing. All these conditions define toxic conditions that require appropriate farming practices (Besser et al. 2017).

Magnesium Hazard: the calculated ionic ratios and parameters illustrate increasing risks of land productivity reduction related to high magnesium content that exceeds locally 90 and 95 magnesium ratios. Hardness is a critical criterion that should be carefully evaluated for water quality as it may not only reduce soil fertility, but it threats the sustainability of irrigation networks and distribution channels (Ramesh and Elango 2012; Nagaraju et al. 2014).

Permeability: Potential salinity reduces greatly the permeability index of the irrigated soil especially for longterm utilization by the accumulation of salt at the surface land and (or) leaching toward deep layers (Ishakuet al. 2011; Nagaraju et al. 2014). The evolution of soil permeability in response to continuous irrigation with low water quality is evaluated through different indices. The results indicate serious threats of reduction of soil permeability and increasing issues related to water infiltration and soil aeration. Kelly ratios exceed locally 1.5, 2, and 3 in Limaguess, Mansoura, and Oum Somaa. The distribution of permeability indices indicates, additionally, that the water samples range from 36 to more than $78 \%$ while only one sample shows a high permeability index. These results reflect serious issues related to long-term irrigation with these waters (Tables 2, 3, 4).

Management indicators: These indices should be taken into account given its harmful effects on soil productivity and clogging problem of water distribution networks (Srivastava et al. 2012).

These indicators are mainly expressed by $\mathrm{HCO}_{3}$-based indicators ( $\mathrm{RSC}$ and $\mathrm{RSBC}$ ), $\mathrm{pH}, \mathrm{CR}$, and $\mathrm{Mg} / \mathrm{Ca}$ ratios. The results indicate that for the majority of the samples waters, the values are within the permissible limits but they reveal increasing risks for long-term irrigation (Fig. 6)

Water quality index: the association of these different classifications in one term summarizing large data set related to different calculated or measured parameters is given by two different indices CWQI and IWQI (Tables 5, 6). The distribution of the calculated indices is given in Fig. 7.

All the sampled waters are of doubtful to unsuitable quality to be used for irrigation and their utilization requires severe restrictions. These synthetic indices explain the cumulative impacts of natural and man-induced factors and confirm that the sustainability of agricultural production even though the most tolerant plant types is facing serious threat unless reliable management is developed. These

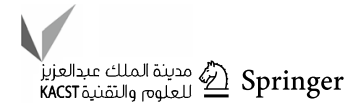


A

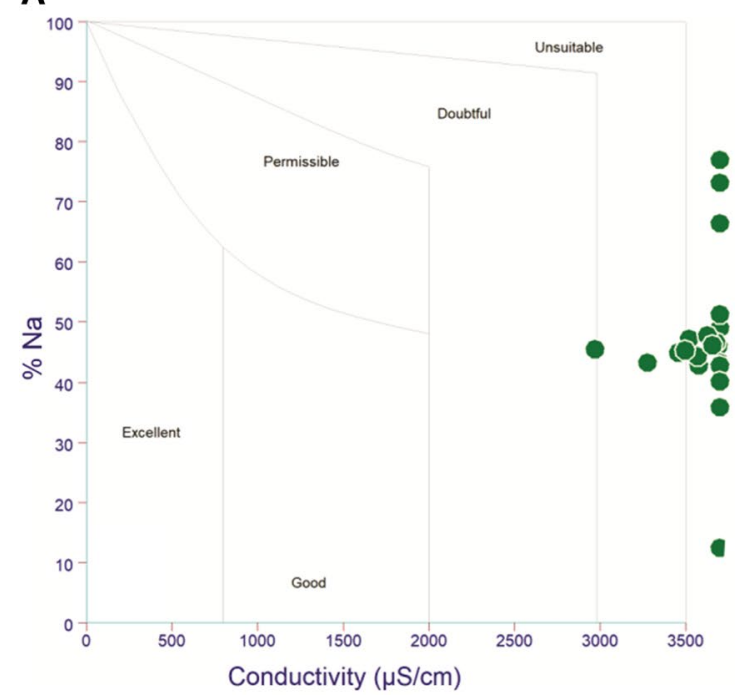

B

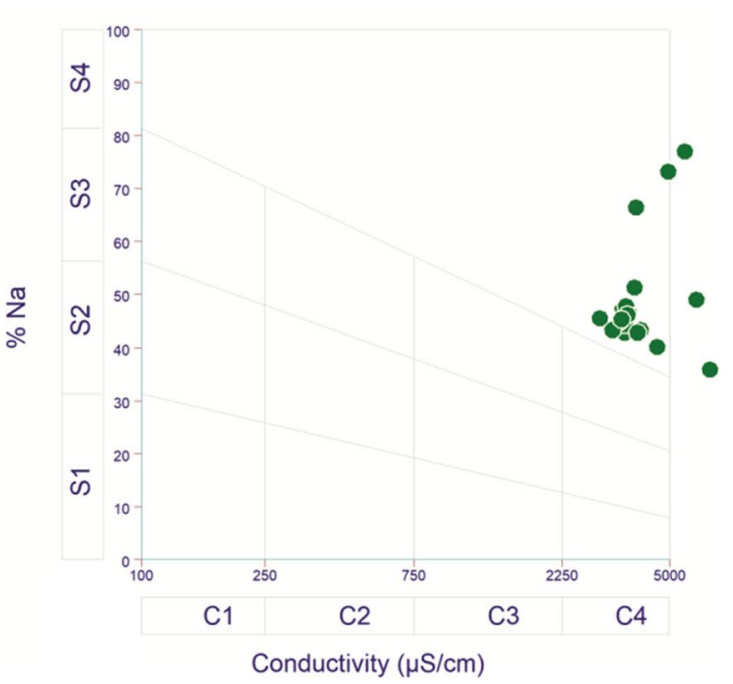

Fig. 3 Distribution of Na percent: a Wilcox diagram; b Riverside diagram

A

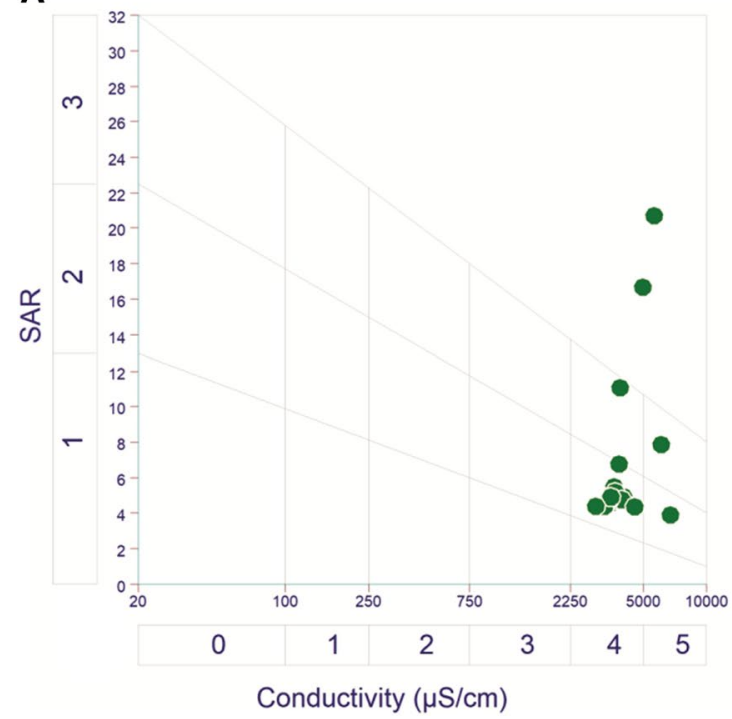

B

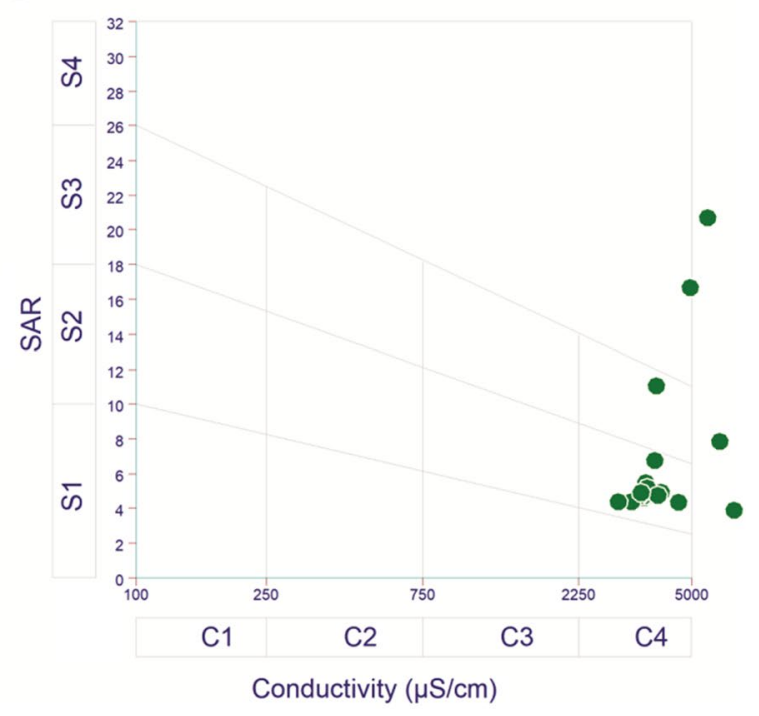

Fig. 4 Distribution of SAR: a Wilcox diagram; b Riverside diagram

results are confirmed by the statistical approaches (Figs. 8 and 9 and Tables 1 and 2).

\section{Irrigation}

\section{Institutional aspect}

According to the study of Karbout et al. (2019) governmental policies are seen as a hindering factor by many farmers. According to farmers, policies concerning water resources management limit their abilities to adopt sustainable practices. Though many governmental policies for the use of natural resources were aimed to preserve these resources, the farmers blame these policies for the deterioration of the oasis. In the same context, the farmers claimed that the state is ignoring their demands to establish cooling ponds for the geothermal water (temperature could reach 45 degrees) used for the oasis irrigation which forces them to seek unsustainable alternative solutions such as illegal wells drilling to extract cold water. The farmers believe that they are unable to adopt sustainable practices because of the low prices of dates and the state is responsible as they have not 

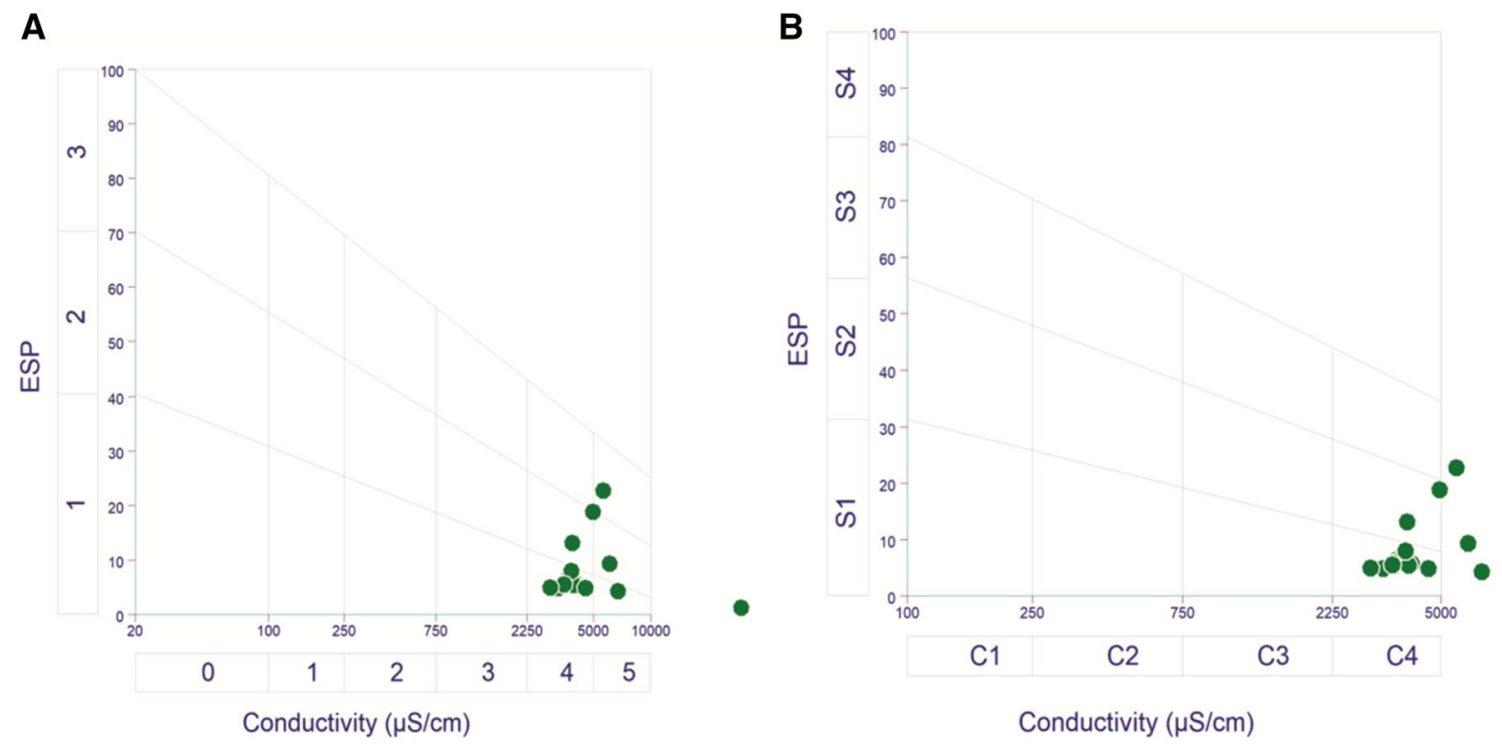

Fig. 5 Distribution of ESP: a Wilcox diagram; b Riverside diagram

Table 2 Pearson correlation of the measured concentrations

\begin{tabular}{|c|c|c|c|c|c|c|c|c|c|c|c|c|c|}
\hline & Depth & $\mathrm{T}$ & $\mathrm{pH}$ & $\mathrm{EC}$ & TDS & $\mathrm{HCO}_{3}$ & $\mathrm{Cl}$ & $\mathrm{NO}_{3}$ & $\mathrm{SO}_{4}$ & $\mathrm{Na}$ & K & $\mathrm{Mg}$ & $\mathrm{Ca}$ \\
\hline Depth & 1.000 & & & & & & & & & & & & \\
\hline $\mathrm{T}$ & 0.173 & 1.000 & & & & & & & & & & & \\
\hline $\mathrm{pH}$ & 0.458 & 0.590 & 1.000 & & & & & & & & & & \\
\hline $\mathrm{EC}$ & 0.286 & -0.035 & -0.171 & 1.000 & & & & & & & & & \\
\hline TDS & 0.036 & 0.480 & -0.004 & 0.002 & 1.000 & & & & & & & & \\
\hline $\mathrm{HCO}_{3}$ & -0.407 & 0.036 & -0.230 & 0.228 & 0.021 & 1.000 & & & & & & & \\
\hline $\mathrm{Cl}$ & -0.034 & -0.126 & 0.037 & 0.097 & -0.086 & -0.036 & 1.000 & & & & & & \\
\hline $\mathrm{NO}_{3}$ & -0.178 & -0.033 & -0.122 & -0.026 & 0.448 & 0.169 & -0.113 & 1.000 & & & & & \\
\hline $\mathrm{SO}_{4}$ & 0.083 & 0.220 & 0.226 & -0.222 & -0.238 & 0.065 & 0.098 & -0.187 & 1.000 & & & & \\
\hline $\mathrm{Na}$ & 0.260 & 0.759 & 0.372 & -0.036 & 0.237 & 0.082 & -0.264 & -0.073 & 0.204 & 1.000 & & & \\
\hline K & 0.218 & -0.008 & -0.218 & -0.136 & 0.504 & -0.099 & 0.030 & -0.075 & -0.138 & 0.265 & 1.000 & & \\
\hline $\mathrm{Mg}$ & -0.066 & -0.107 & -0.234 & 0.363 & -0.083 & 0.122 & 0.042 & -0.098 & 0.107 & -0.183 & -0.248 & 1.000 & \\
\hline $\mathrm{Ca}$ & -0.244 & 0.017 & 0.135 & -0.075 & -0.120 & 0.044 & 0.337 & -0.017 & 0.408 & -0.059 & -0.041 & 0.171 & 1.000 \\
\hline
\end{tabular}

Table 3 Distribution of the calculated ionic ratios

\begin{tabular}{lrlrll}
\hline & MH & TH & KR & PI & PS \\
\hline Good & 10.71 & $0 \%$ & 7.14 & $0 \%$ & 0 \\
Doubtful & 85.72 & 28.57 & 75.28 & 92.86 & 81.82 \\
Unsuitable & 3.57 & 71.43 & 17.85 & 7.14 & 18.18 \\
\hline
\end{tabular}

provided a unit price for dates and conditioned stores for date crops, which affect the prices and thus the financial situation for the farmers to enable them to adopt sustainable management practices. The ignorance and lack of appreciation to the farmer's demands by the state are believed to have negative effects on the acceptance and adoption of sustainable management practices (Okoba and Graaff 2005). However, in developing countries, the governmental policies to encourage the adoption of sustainable practices are greatly linked to the availability of funding resources (Rodriguez et al. 2009). In the study area, the main governmental organizations having important contributions in supervision, control, information diffusion, vulgarization, and initiative adaptation are the Ministry of Agriculture with its different sub-organisms with national and local activities, the Ministry of Defense especially at Rijim Maatoug, the Ministry of Environment. Besides these hierarchical institutions, the civil and scientific committee has a leading role in agricultural development such as the interprofessional group of dates, the cooperation of agricultural services association, 
Table 4 Pearson correlation of the calculated ionic ratios

\begin{tabular}{|c|c|c|c|c|c|c|c|c|c|c|}
\hline & $\mathrm{EC}$ & TH & $\mathrm{MH}$ & PI & $\mathrm{KR}$ & SSP & SAR & PS & PerNa & RSC \\
\hline $\mathrm{EC}$ & 1.000 & & & & & & & & & \\
\hline $\mathrm{TH}$ & -0.086 & 1.000 & & & & & & & & \\
\hline $\mathrm{MH}$ & 0.543 & 0.057 & 1.000 & & & & & & & \\
\hline PI & -0.593 & 0.040 & -0.353 & 1.000 & & & & & & \\
\hline $\mathrm{KR}$ & -0.247 & -0.007 & -0.121 & 0.683 & 1.000 & & & & & \\
\hline SSP & -0.340 & -0.149 & -0.220 & 0.352 & 0.539 & 1.000 & & & & \\
\hline SAR & -0.215 & 0.248 & -0.124 & -0.207 & -0.535 & -0.248 & 1.000 & & & \\
\hline PS & -0.122 & 0.284 & 0.041 & 0.057 & -0.038 & 0.088 & 0.130 & 1.000 & & \\
\hline PerNa & 0.638 & -0.189 & 0.286 & -0.308 & -0.144 & -0.384 & -0.182 & -0.391 & 1.000 & \\
\hline RSC & -0.414 & -0.145 & -0.060 & 0.288 & 0.177 & 0.557 & -0.065 & -0.118 & -0.249 & 1.000 \\
\hline
\end{tabular}

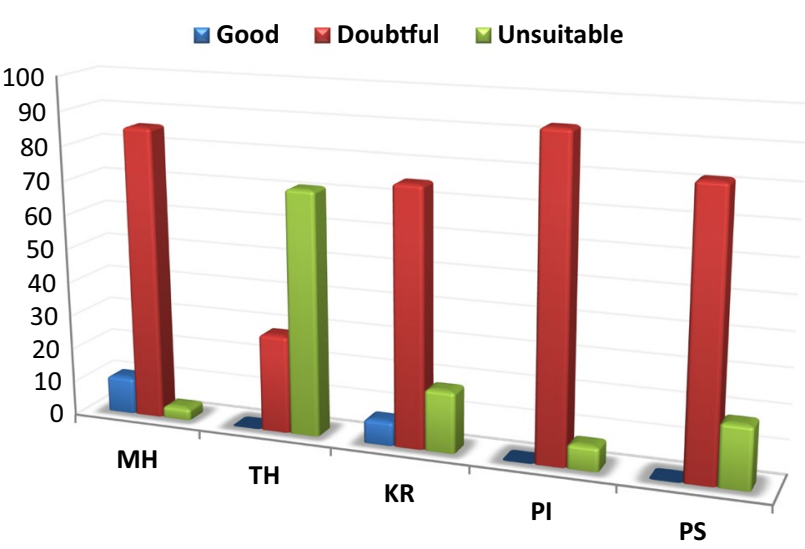

Fig. 6 Distribution of water quality indices the association of agricultural development. All these actors have deeply controlled the adopted strategies and have conducted several courses, conferences, and projects for local farmer benefits such as PDES, APIOS, GDEO... However, given the non-systematic control and the lack of a clear calendar of intervention, the activities of these numerous poorly collaborated organizations and actors are still limited.

\section{Irrigation methods}

The inter-linkages between the different factors of cycle production are reflected by this vicious series of equations and estimation. The estimation of water requirements for date palms relies on the evaluation of irrigation efficiency

Table 5 The used WQI expressions

\begin{tabular}{|c|c|c|}
\hline Water Quality Index & Expression & Parameters \\
\hline $\begin{array}{l}\text { IWQI } \\
\text { Ayers and Westcot (1999); } \\
\text { Meireles et al. (2010) }\end{array}$ & $\begin{array}{l}\mathrm{IWQI}=\sum \mathrm{Q}_{\mathrm{i}}{ }^{*} \mathrm{~W}_{\mathrm{i}} ; \\
\mathrm{Q}_{\mathrm{i}=\mathrm{Qi}}{ }_{\max }-\left[\left(\mathrm{X}_{\mathrm{ij}}-\mathrm{X}_{\mathrm{inf}}\right) * \mathrm{Q}_{\mathrm{i} \text { amp }} / \mathrm{X}_{\mathrm{amp}}\right]\end{array}$ & $\begin{array}{l}\mathrm{Q}_{\mathrm{i}}=\text { non dimensional number depending on tolerance limits; } \\
\mathrm{Q}_{\mathrm{i} \text { max }}=\text { maximum value of the category; } \\
\mathrm{X}_{\mathrm{ij}}=\text { parameter spotted value; } \\
\mathrm{X}_{\mathrm{inf}}=\text { minimum border category; } \\
\mathrm{Q}_{\mathrm{i} \text { amp }}=\text { category ampleness; } \\
\mathrm{X}_{\text {amp }}=\text { category ampleness for each parameter; estimated by } \\
\text { considering the upper most border (limit) as the maximum } \\
\text { value obtained the highest value determined) in the physical } \\
\text { and chemical analysis of water sample; } \\
\text { Wi = weight of the ith parameter }\end{array}$ \\
\hline $\begin{array}{l}\text { CWQI } \\
\text { CCME (2001); } \\
\text { Ayers and Westcot (1999) }\end{array}$ & $\begin{array}{l}\mathrm{CWQI}=100-\left(\left(\mathrm{F}_{1}^{2}+\mathrm{F}_{2}^{2}+\mathrm{F}_{3}^{2}\right)^{1 / 2} / 1.732\right) \\
\mathrm{F}_{1}=100 * \text { Number of failed variables / Total } \\
\quad \text { number of variables; } \\
\mathrm{F}_{2}=100 * \text { Number of failed tests / Total number } \\
\quad \text { of tests; } \\
\mathrm{F}_{3}=\text { nse } /(0.01 \text { nse }+0.01) ; \\
\mathrm{Nse}^{n}=\sum_{i-1}^{n} \frac{\text { excurions }^{\text {numberoftests }}}{\text { Excursion }_{\mathrm{i}}=\left(\text { Failed test value }_{\mathrm{i}} / \text { Objective }_{\mathrm{j}}\right)} \\
\quad-1 \text {; if the variable is greater than the objec- } \\
\quad \text { tive; } \\
\text { Excursion } \\
\quad-1 \text {; if the test value falls below the guideline }\end{array}$ & $\begin{array}{l}\mathrm{F}_{1}=\text { Scope; } \\
\mathrm{F}_{2}=\text { Frequency; } \\
\mathrm{F}_{3}=\text { Amplitude; } \\
\text { Nse = normalized sum of excursions; }\end{array}$ \\
\hline
\end{tabular}


Table 6 The used parameters and weights (Meireles et al. 2010)

\begin{tabular}{ll}
\hline Parameter & Weight \\
\hline $\mathrm{EC}$ & 0.211 \\
$\mathrm{Na}$ & 0.204 \\
$\mathrm{HCO}_{3}$ & 0.202 \\
$\mathrm{Cl}$ & 0.194 \\
$\mathrm{SAR}$ & 0.189 \\
\hline
\end{tabular}

and scheduling (FAO 2007). Previous works proved that local irrigation methods and micro-techniques used for irrigation show a higher level of efficiency while traditional flood type is considered as a loss of water resources and loss of productivity factor (FAO 2007; Dhaouadi et al. 2017, 2020). Changes in irrigation methods raise the concern of societal and economic partners of the oasis landscape and define the role of the newer technologies in resources sustainability. However, most of the local population, for decades now, has used flood or surface irrigation relative to long traditional practices since the nomad population.
The soils of Nefzaoua oasis are classified as Gypsisols according to WRB. The sandy soils of the oasis are characterized by high permeability and low water retention (Kadri and Van Ranst (2002). Groundwater and soil salinity varies with water table depth. The study area is irrigated by a surface irrigation system, the plots of date palm plantations are connected with drainage collectors that are installed in the salt depression of Chott Djerid. The vegetation cover of Nefzoaua oasis is composed mainly of date palm (Phoenix dactylifera L.) dominated by DegletNourvariety, and alfalfa (Medicago sativa) fodder crop for its high salt tolerance (Mezni et al. 2002). Water management of irrigation water is carried out by the Collective Interest Association (AIC) and the water distribution is made based on the irrigation schedule decided by AIC with the assistance of the regional commissariat for agricultural development CRDA. In Tunisian southern oases date, palm groves are irrigated through the surface irrigation system. Farrow and basin techniques are considered as modified forms of flood techniques in which water is directed to flow through narrow channels established between palm trees rows (Figs. 9 and 10). While

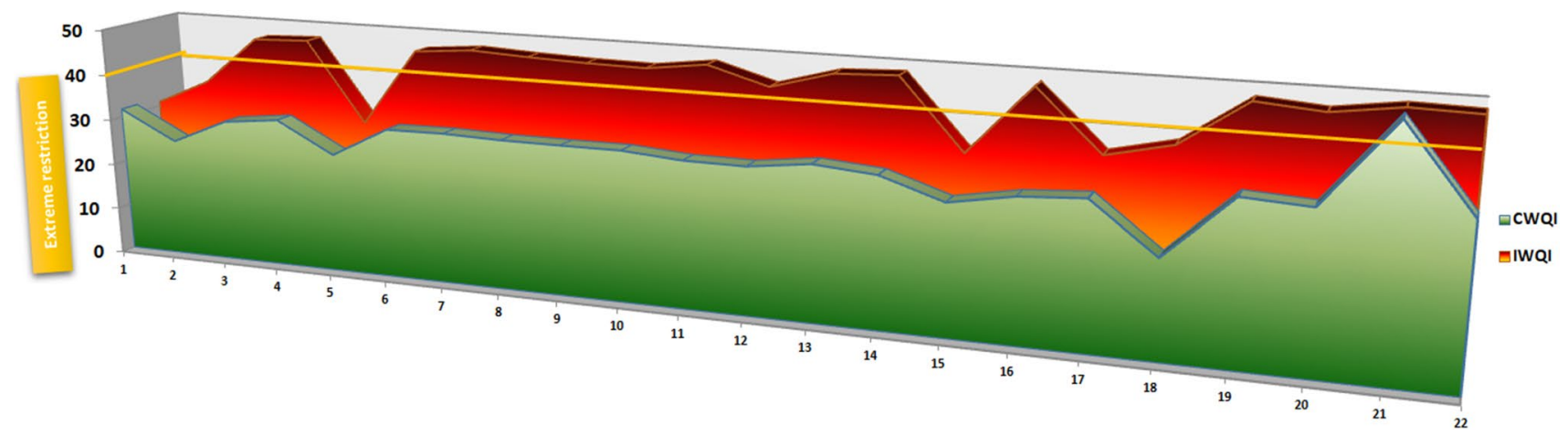

Fig. 7 Distribution of CWQI and IWQI

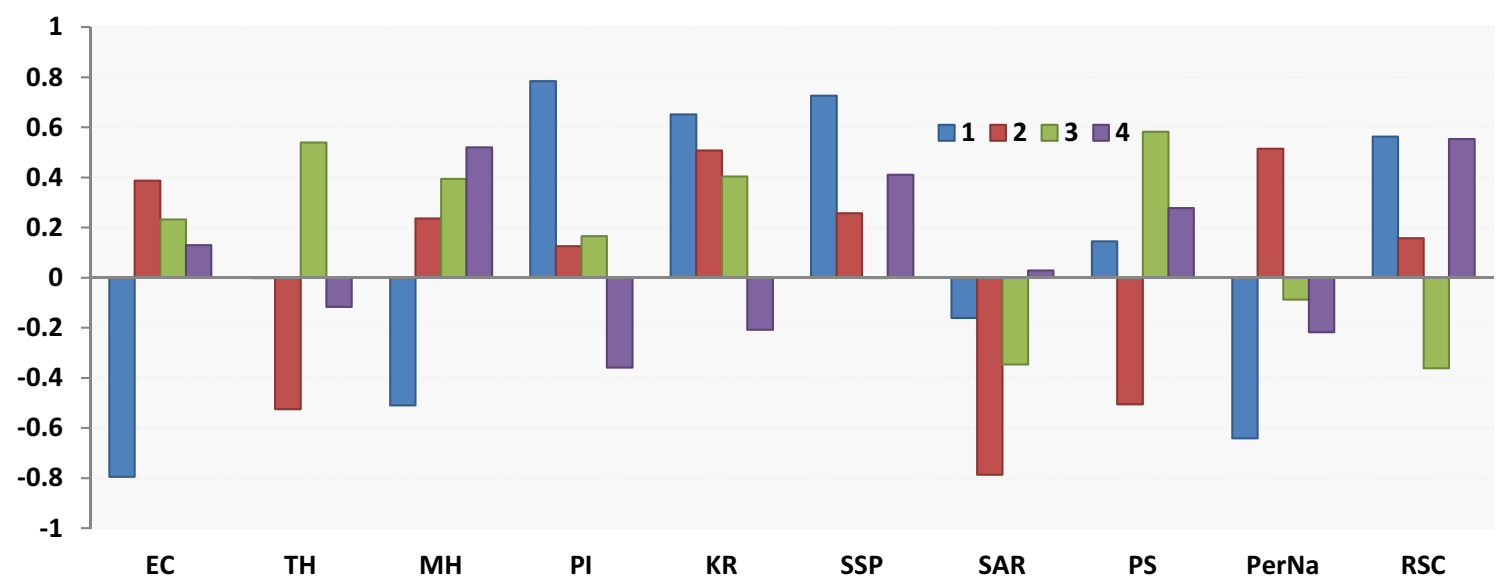

Fig. 8 PCA output based on the calculated ionic ratios 


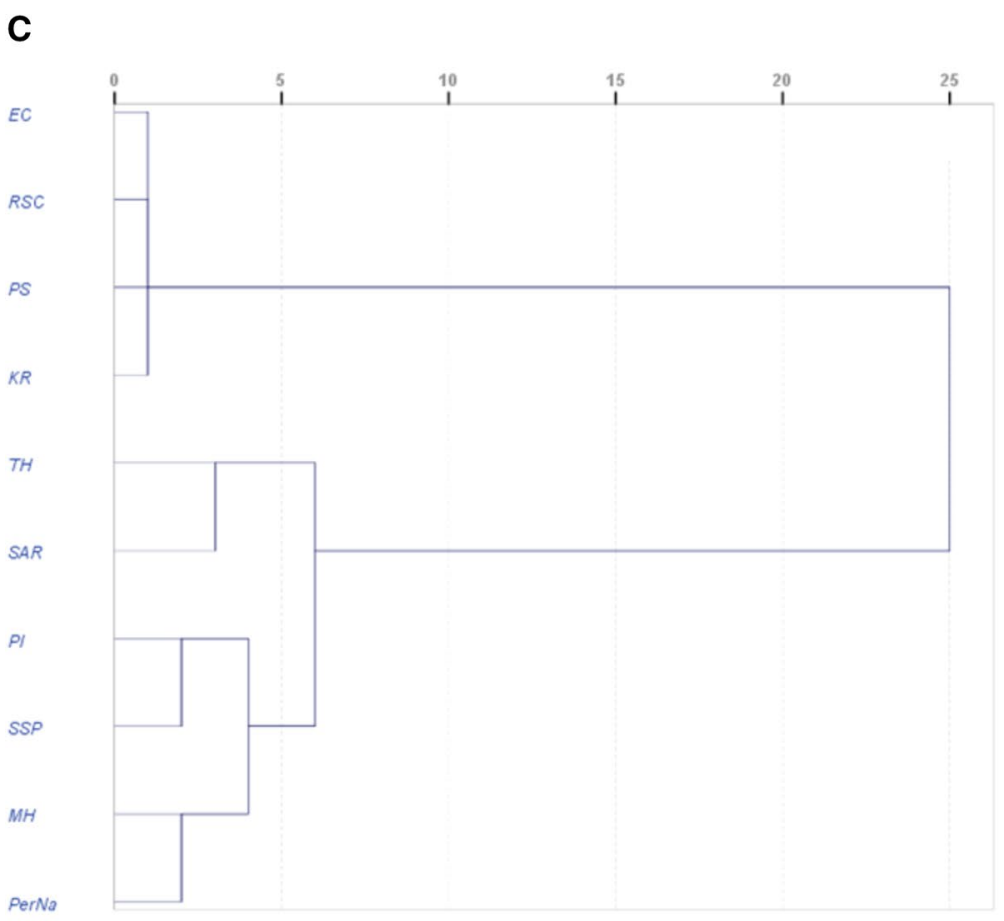

A
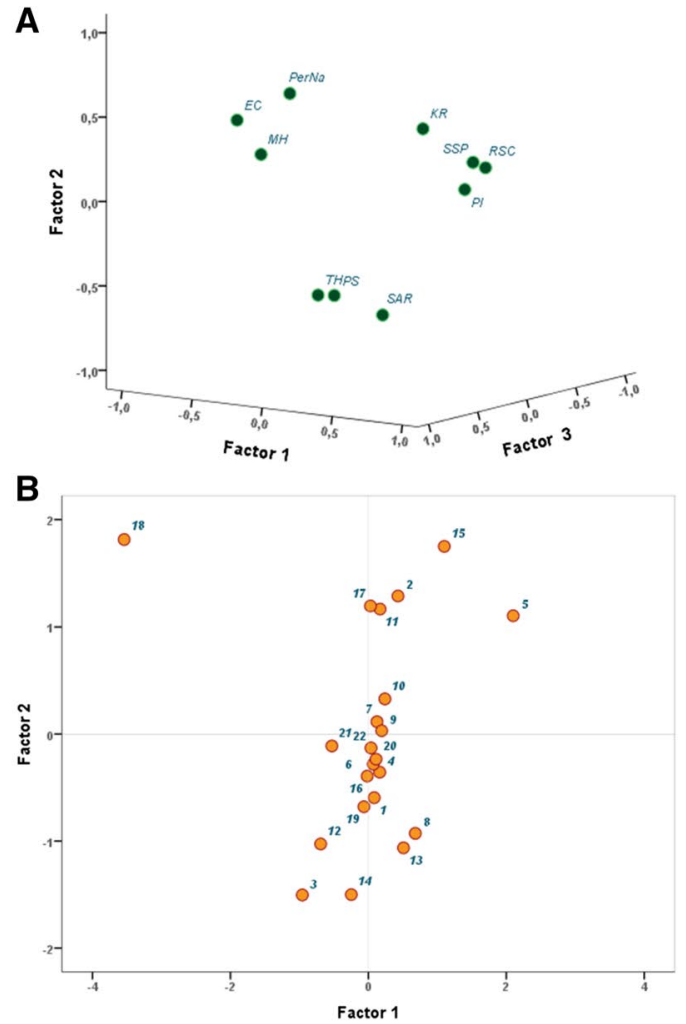

Fig. 9 Statistical results

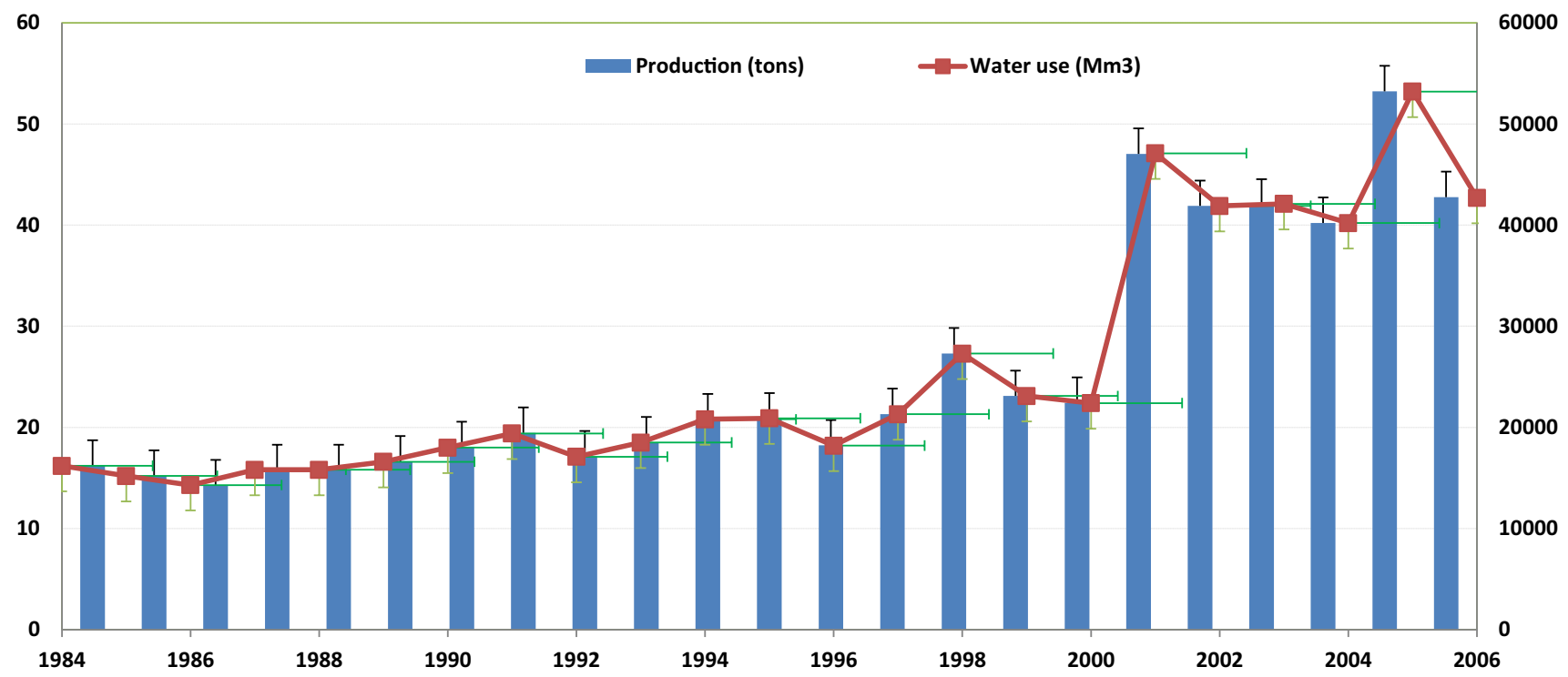

Fig. 10 Water use efficiency

this method is less expensive and easily managed in flatted lands nevertheless, the technique suitability in sandy soils is rather low due to the high loss of water through leaching and evaporation. The depletion of water resources is a major problem in the southern oases of Tunisia, the so-called illegal extension of oases as a result of private initiatives and access to water through digging wells has led to the overextraction of renewable groundwater, and the accelerating phenomenon of saline intrusion from the saline areas (e.g., ChottDjerid in Kebili) (Omrani 2011). In addition, most of 
the farmers managed the water in their way in the absence of a specific recommended method which leads to considerable water loss (Dhaouadi et al. 2015).

The modern irrigation system cannot gain popularity in these regions concerning the economic and religious value of oases, despite the encouraging results of these systems in different countries all over the world having similar conditions. Thus, these newer techniques, for example, microtechniques of irrigation that as the highest efficiency feedback, are limited to some pilot stations (Dhaouadi et al. 2017). Local farmers refuse often to abandon traditional methodologies and choose the historical reliance above modern technologies. The collected data from field investigations with a high level of reliable data reflect the refusal of land stakeholder's the trial of misunderstood newer technologies. Many Pilot stations have been implanted in several oases in southwestern Tunisia while the results are not sufficiently encouraging given the used classic approaches of development of these stations related principally to the lack of information diffusion to local farmers which reduces largely the confidence and the acceptance of local population.

\section{Irrigation scheduling}

Irrigation efficiency assessment requires reliable data about some physical characteristics such as planting density, irrigation scheduling, soil texture, root zone description... and other chemical parameters namely the issues related to irrigation water quality. Even though effective irrigation scheduling may save a huge percentage of water resources, little works have been published about this issue in the study area. This may be explained by the uncontrolled distribution of irrigation. Field survey indicates that, according to the used methodology based on cycle turn of irrigation, the oases... for three or four months and then they will be irrigated with a cumulative quantity, which will considerably affect the productivity of these plantations by exceeding, in one hand, the tolerant limit of physiological drought and on the other hand, by inducing local water logging problems and increase of water table depth during cumulative irrigation.

Besides these problems related to the scheduling of irrigation controlled by the governmental institution the illicit drilling, uncontrolled quantity by which palm plantation according to unknown calendar reveals huge constraints for agricultural development. Illicit drilling of water resources is driven by the water shortage for irrigation purposes and the expansion of new date palm plantations which demands that there be enough water to meet the irrigation requirements. Similarly, given the illegal expansion of date palm plantations, undoubtedly, farmers seek to increase their production of dates. Their focus is on extracting maximum revenues from the oasis in the short term, which consequently leads to the adoption of practices that could harm the oasis macrosystem. Similar to illicit drilling of water resources, indicated that illegal expansion of date palm plantation is considered as a direct cause of oasis degradation.

This mismanagement is observed in the study area as the irrigation calendar with circular tower varies from 5 to 15 days and may exceed in case of lack of maintenance three months of physiological droughts. Moreover, the delivered quantity for traditional, and modern oases is of a mean of $0.75 \mathrm{l} / \mathrm{s} / \mathrm{ha}$ so $3 \mathrm{~h}$ per hectare while for illicit parcels the irrigation is uncontrolled and the quantities are not accurately measured. For both types, the quantities of irrigation water are not a calculated function of the real requirements of the cultivated crops which will reduce the efficiency of the irrigation and will have adverse impacts on soil fertility, crop quality, and agricultural sustainability.

\section{Irrigation efficiency}

Generally, countries assess the water requirements of date palms using theoretical calculation (Mihoub et al. 2015; Haj-Amor et al. 2017; Al-Omran et al. 2019). This estimation reveals often uncertainties related to some factors that gross water requirements like irrigation methods, irrigation scheduling, varieties, disease, and evapotranspiration (FAO 2007; Abdelhadi et al. 2020). The suitability of water quality and the management of the available resources becomes a critical issue challenging land productivity and requirements estimation (Abdelhadi et al. 2020).

According to Dhaouadi et al. (2020), the distribution of water quality for date palm in southern Tunisia has a mean of one time and a half the real requirements of palm and may reach locally 4 or 5 times the desired limits. Irrigation water productivity of palm in Djemna, Rijim Maatoug, and Tozeur was $0.23,0.23$, and $0.25 \mathrm{~kg} \mathrm{~m}^{-3}$, respectively, which is largely below those measured for different Arabian countries based on date palm production.

The efficiency of the irrigation in the study area can be evaluated as well by the correlation between irrigation water number, production, and agricultural area expansion. According to the collected data, the number of illicit wells exceeds 4000 wells in 2018 according to CRDA (2018).

\section{Farming system}

\section{Planting density and intercropping}

Despite the difficult climate conditions, the area is well known for intense agricultural production resulted in the increasing vulnerability of these soils to acidification and salinization issues.

Given the difficult climate conditions and desert outfit of the overall landscape of the area, a basic need for flourishing ecological sustainable eco-development highlights

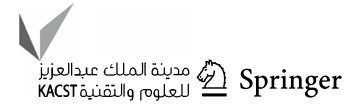


the pressure on ecological disturbing and biodiversity. In the study area, traditional oases are characterized by different types of cultivation namely palm plantations, fruit trees, and low crops (forages, vegetables....). According to the obtained data from field investigation, the density of date plantation differs according to the oasis types. The traditional oasis (covering about 58\% of the study area and less than $37 \%$ from the agricultural area of SW Tunisia), the value was about 150 to 200 trees per hectare while for the modern oasis (represented by $35 \%$ in the study area) and illicit parcels (about $7 \%$ of total agricultural land in the investigate area) the value decreased to $100-150$ depending in the distance between trees that varies from 7 to 8 and $10 \mathrm{~m}$.

According to Mekki et al. (2013), the illegal expansion of date palm plantation in Nefzaoua oasis reached 15\% of the original oasis area and the farmers keep asking the authorities to register this expansion under land records to make these expansions legal. Though illicit drilling of water resources and illegal expansion of date plantations are also considered as land mismanagement practices, the mismanagement may also comprise of other practices that threaten the sustainability of the oasis.

\section{Indigenous knowledge of local farmers}

Efficient agricultural production for the management of land degradation issuer hinges on the indigenous knowledge of local farmers, especially in these community-managed oases. One of the constraints hindering the farmers from adopting best management practices is the lack of know-how knowledge. The lack of expertise and low capacity of this category of farmers can be partly attributed to the absence of extension services and capacity-building programs for the farmers. Several studies have indicated that a lack of knowledge and land management expertise can significantly affect the adoption of sustainable practices. The problem of low skills and awareness is aggravated by the low level of education for most of the farmers running the farming activities. Farmers also may not find practices that demand intellectual or educational level attractive (Vanclay and Lawrence 1994). Many practices on the farm require specific skills and knowledge of the whole system inputs such as soil, water, and climate, farmers may feel unable to develop or adopt certain practices as they lack these skills (Van Mele et al. 2009). Thus, applying practices in a complex agricultural system such as oasis agro-system may have a high risk of failure if the farmers do not consider all the components, which ultimately will affect the farmers' perception of the sustainable management practice technologies may also hinder the farmers from adopting new practices as their effects are not immediately recognized or need more time to attain their outcomes (Rodriguez et al. 2009). This process can be achieved. In addition, the scarce information regarding economic or technical issues of a new practice in Nefzoaua oasis challenges the initiative participation if the farmers show eagerness and commitment to apply sustainable practices to combat the degradation.

Despite their limited knowledge of biodiversity and environmental issues, according to Karbout et al.(2019), the farmers in the oasis have supported a wide range of plants and crops in the past, but now only tolerant crops are grown, i.e., date palm and some fodder varieties. The farmers may engage in sustainability practices without considering the effects of these practices on the environment quality or the ecological cycles but rather to recover their land from particular stress or maintain the soil fertility. The farmers in Nefzaoua apply some sustainable practices (Fig. 11) to cope with the degradation of the soil and alleviate the effect of soil salinity and waterlogging (Karbout et al. 2019). Most of the farmers apply sands mixed with animal manure to enhance soil fertility (Karbout et al., 2019). The farmers are distancing themselves from their responsibility of combating the degradation through paying more effort in introducing sustainable practices. This indicates that farmers are acting passively toward adopting more sustainable practices, thus they tend to cast the responsibility of combating degradation on the government and factors that are beyond their control.

The knowledge of land management from other farmers (farmer-to-farmer knowledge), through interaction with the surrounding environments, farmers may have developed practices using their intelligence as they observe what is going around them and make their experiments and decisions over the adoption of the effective practices namely as a sandy amendment, biodiversity enhancement, reintegration of biologic compost, community collaboration for irrigation network amelioration and maintenance, ameliorated gravity irrigation system. The practices are disseminated among farmers because of the strong social interaction and relations. In addition, farmers seem to be more influenced by the experience of other farmers than the recommendations from the extension services. They share information and collaborate as they see the success of others when adopting specific practices that help them in attaining their goals. In their study, Baumgart-Getz et al. (2012) recommend when implementing conservation practices to utilize farmerto-farmer information dissemination as this strategy can increase individual capacity and awareness by using farmer networks to highlight the achievements and benefits realized by those who adopted the practices earlier. Nowak (1992) suggested involving groups of local farmers and landowners working on effective solutions when conducting agricultural extension to solve conservation problems, and to promote farmer-to-farmer learning opportunities. This method is believed to have high impacts on the farmers' awareness and improve their knowledge of degradation solutions and 
Fig. 11 Irrigation system on the study area
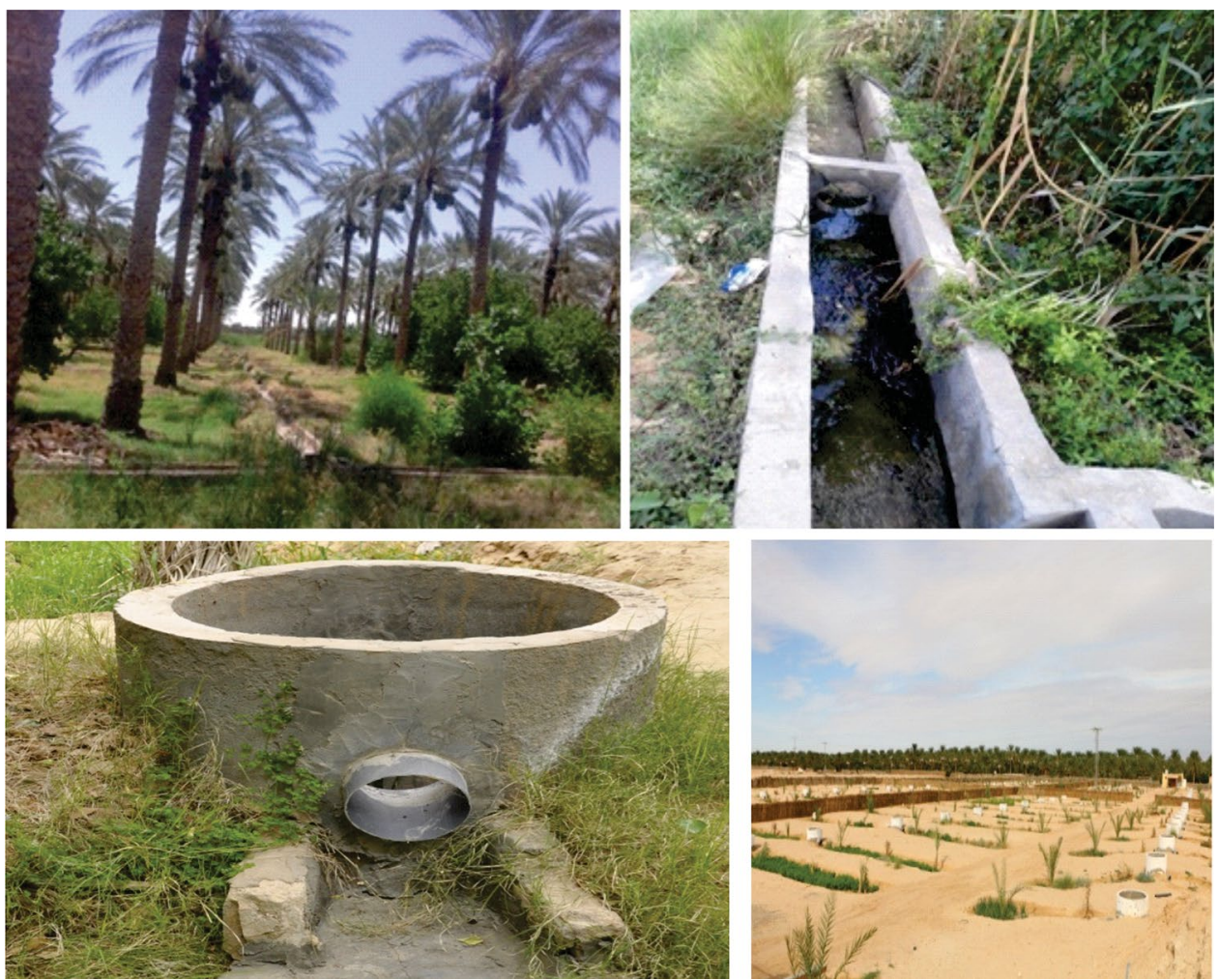

enhances disseminating of valuable skills among farmers, i.e., manuring, building drainage canals or windbreakers. Additionally, the method encourages networking between the farmers from different areas and improves their organizational structure which can enhance their influence on the authorities. Also, farmers inherited traditional practices from their ancestors. This can be explained by variance in the current problems of the oasis from what they were in the past. Thus, old practices may no longer be useful in addressing today's oasis issues. For example, crop rotation was widely used in the past by the oasis farmers, today many crops are no longer grown because of the soil salinity or high temperatures. Therefore, crop rotation practices become less common in the oasis. Moreover, the farmers have been interested in the activities of some civil organizations encouraging reasonable exploitation of oasis natural resources at local scale via several interventions such as the implementation of drip irrigation system (Beni Ghrib society introduced bubbler irrigation system under date palm (from 9 farmers in 2011 to 103 participated farmers in 2020)). These actions have proved their efficiency given the increasing percentage of social satisfaction concerning other management practices.

Although agricultural extension offered by the specialized departments has long been recognized as an important factor in promoting agricultural development and is seen as a key element for enabling farmers to obtain information and technologies to improve agricultural practices, (Gebremedhin et al. 2009; Lacoue-Labarthe et al. 2011), in Nefzaoua region a small number of farmers acquire their knowledge about land management practices from the agricultural extension services and state rules and regulations, respectively. This reflects the low degree of activity of the state extension services of the oasis. The farmers emphasized that the presence of the extension department is mostly insignificant in the oasis and the frequency of extension visits to farmers is low.

\section{Synthesis: Future options to oases management}

The findings of this multi-disciplinary research indicate that the tolerance of date cultivation in the study area has become a subject of concern with continuous degradation of natural resources within unpredictable environmental changes and climate variability. The sustainability of these cultures, closely related to the availability of water resources and management, is threatened by an index of productivity of about $0.28 \mathrm{~kg} / \mathrm{m}$ according to the statistics of FAO (2007). This index is predicted to be less than 0.2 under present-day conditions, given the continuous loss of irrigation water to evaporation and waterlogging problems within unreasonable management without any respect for the real water requirements of the cultivated crops (Fig. 12).

The conservation of date palm heritage and the maintenance of agricultural production in this hyper-arid region in southern Tunisia require future management actions involving advances in social and technologic aspects for an

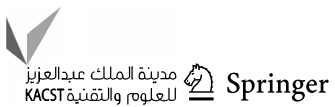


Date palm sustainability

Southern Tunisia

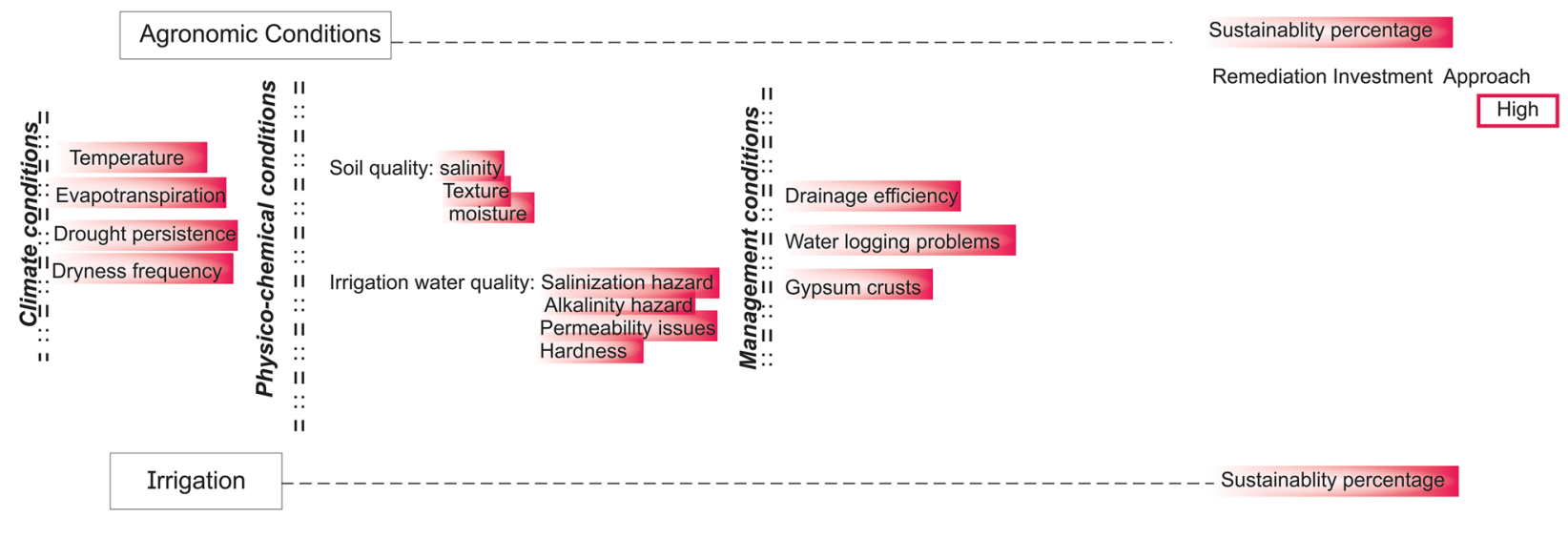

Remediation Investment Approach
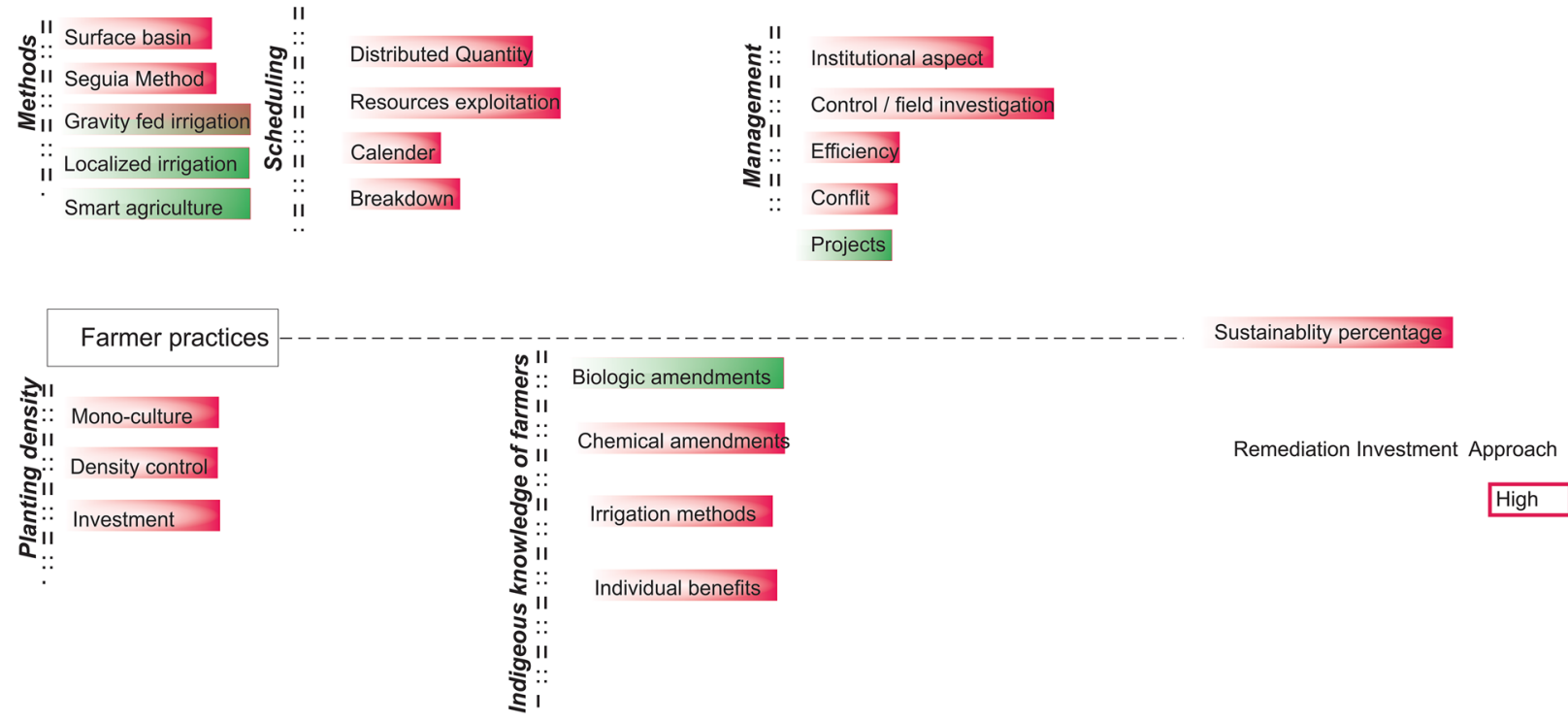

Fig. 12 Synthetic evaluation of factors influencing date palm production

efficient benefit-cost ratio and healthy ecological functioning. Regard the salt-water imbalance and the limited water resources, the use of non-conventional resources is necessary on the one hand and the update of irrigation techniques is crucial on the other hand. Nevertheless, to address these changes a critical socio-cultural assessment is required. These future opportunities to implement sustainable development of this cultivation should evaluate the combined effect of irrigation management and agricultural practices on dates crop and quality within a shared task between institutional and economic partners and societal perceptions (Al-Muaini et al. 2019). Many projects have failed (Fig. 11) due to farmer awareness from modernization programmers and (or) institutional-economic systems and their relative constraints to achieve the expected benefits (Ghazouani and
Marlet 2009). In these community-managed oases, degradation and infertility issues are not reported by farmers due to several factors namely field scale, poor investment and poor maintenance, intermittent distribution of irrigation water, night irrigation, and lack of farmer commitment to collective rules (Ghazouani and Marlet 2009; Besser et al. 2018; Dhaouadi et al. 2020).

\section{Conclusions}

Given the economic, ecological, and social dimensions of date palm cultivation, this work represents an accurate evaluation of different driving forces influencing the sustainable development of these agro-systems. To bring 
economic profitability, optimize water use, crop variety with the sustainable ecological environment, knowledge about techniques for variety adaptability, local agro-management system, irrigation scheduling, and aridity-resources-productivity balance design must be carefully broadening.

The results of the study indicate that progressive land degradation is the combination of effects of many factors mainly high saline water (salinity hazard) used for irrigation (EC between 674.4 and $5450 \mu \mathrm{s} / \mathrm{cm}$ ), high sodium adsorption ratio SAR exceeding 20, inappropriate irrigation scheduling, traditional basin irrigation methods with low efficiency and indigenous knowledge. Climate change has enhanced furthermore the degradation of crop quality and quantity.

Taking into account all of these factors, farmers should be considered as permanent participants in the management process of all projects, addressing different recommendations technical, economic, agronomic, societal, and ecological such as fundamental research based on field comparison between oasis and projects and strategies encouraging farmer-to-farmer knowledge transfer, facilitating farming investment, information diffusion and technical and engineering support.

Author's contributions All the cited authors have participated in the development and revision of the manuscript.

Funding This research did not receive any specific grant from funding agencies in the public, commercial, or not-for-profit sectors.

Data availability The data will be available on request.

Data code It will be available on request.

\section{Declaration}

Conflict of interests The authors declare that they have no known competing financial interests or personal relationships that could have appeared to influence the work reported in this paper.

Open Access This article is licensed under a Creative Commons Attribution 4.0 International License, which permits use, sharing, adaptation, distribution and reproduction in any medium or format, as long as you give appropriate credit to the original author(s) and the source, provide a link to the Creative Commons licence, and indicate if changes were made. The images or other third party material in this article are included in the article's Creative Commons licence, unless indicated otherwise in a credit line to the material. If material is not included in the article's Creative Commons licence and your intended use is not permitted by statutory regulation or exceeds the permitted use, you will need to obtain permission directly from the copyright holder. To view a copy of this licence, visit http://creativecommons.org/licenses/by/4.0/.

\section{References}

Abdelhadi AW, Salih AA, Sultan K, Alsafi A, Tashtoush F (2020) actual water use of young date palm trees as affected byaminolevulinic acid application and different irrigation water salinities. Irrig.and Drain.

Ali HG (2010) Development of Date Palm Cultivation and Its Role in Sustainability of Agriculture in Oman.Acta Hort. 882, ISHS 2010

Al-Hadithi M (2012) Application of water quality index to asses suitability of groundwater quality for drinking purposes in RatmaoPathriRaso watershed, Haridwar District, India. Am J SciInd Res. https://doi.org/10.5251/ajsir.s012.3.6.395.402

Alhammadi M, Al Shrouf A (2013) Irrigation of sandy soils, basics and scheduling. Environ Sci. https://doi.org/10.5772/55117

Al-Muaini A, Green S, Dakheel A, Abdullah A-H, Abdelwahid W, Dixon S, Kemp P, Clothier B (2019) Irrigation management with saline groundwater of a date palm cultivar in the hyper-arid United Arab Emirates. Agricult Water Manage 211:123-131. https://doi. org/10.1016/j.agwat.2018.09.042

Al-Omran MA, El-Maghraby SE, Aly AA, Al-Wabel IM, Al-Asmari ZA, Nadeem ME (2013) Quality assessment of various bottled watersmarketed in Saudi Arabia. Environ Monit Assess 185(8):6397-6406. https://doi.org/10.1007/s10661-012-3032-z

Al-Omran AM, Awad M, AlHarbi M, Nadeem M (2018) Hydrogeochemical characterization and groundwater qualityassessment in Al-Hasa, Saudi Arabia. Arabian J Geosci 11:79. https://doi.org/ 10.1007/s12517-018-3420-y

Al-Omran A, Eid S, Alshemmary F (2019) Crop water requirements of date palm based on actual applied water and Penman-Monteith calculations in Saudi Arabia. Appl Water Sci 9:69-74

Al-Muaini A, Dakheel A, Green S, Abdullah A, Abdul Rahman AQ, AbouDahr WA, Dixon S, Clothier B (2017) Irrigationmanagement with saline groundwater of date palm cultivars in the hyperarid United Arab Emirates. In: Eds LD Currie, Hedley MJ (eds.) Science and policy: nutrientmanagement challenges for the next generation. http://flrc.massey.ac.nz/publications.html. OccasionalReport No. 30.Fertilizer and Lime Research Centre, Massey University, Palmerston North, New Zealand.11 pages.

Al-Muaini A, Green S, Dakheel A, Dixon S, Clothier B (2018) Trunk sap flowin date palms growing in the UnitedArabEmirates. Acta Hortic 1222:127-134. https://doi.org/10.17660/ActaHortic.2018. 1222.28

Al-Taani AA, Batayneh A, Mogren S, Nazzal N, Ghrefat H, Zaman H, Elawadi E (2013) Groundwater Quality of Coastal Aquifer Systems in the Eastern Coast of the Gulf of Aqaba, Saudi Arabia. J Appl Sci Agric 8:768-778

APHA (1998) Standard methods for the examination of water and wastewater, 20th edn. American Public Health Association, WashingtonDC

Appelo CAJ, Postma D (1996) Geochemistry, groundwater and pollution.A.A. Balkema, Rotterdam

Ayers RS, Westcot DW (1985) Water quality for agriculture. FAO irrigation and drainage paper no 29, Rev. 1. U. N. Food and Agriculture Organization, Rome

Ayers RS, Westcott DW (1999) The water quality in agriculture, 2nd Campina Grande. UFPB, Studies FAO Irrigation and Drainage, p 29

Batayneh A, Al-Taani A (2015) Integrated resistivity and water chemistry for evaluation of groundwater quality of the Gulf of Aqaba coastal area in Saudi Arabia. Geosci J. https://doi.org/10.1007/ s12303-015-0053-y

Baumgart-Getz A, Prokopy L, Floress K (2012) Why farmers adopt best management practice in the United States: a meta-analysis of the adoption literature. J Environ Manage 96:17-25. https://doi. org/10.1016/j.jenvman.2011.10.006 
Bingham, F. In: Page AL et al (eds) Boron, methods of soil aNalysis, part-2, ed., edited. (ASA, SSA, Madison, 1982).

Besser H, Mokadem N, Redhaouania B, Rhimi N, Khelifi F, Ayadi Y, Omar Z, Bouajila A, Hamed Y (2017) GIS based model evaluation of groundwater quality and estimation of soil salinization and land degradation risks in arid Mediterranean site (SW Tunisia). Arab J Geosci 10:350. https://doi.org/10.1007/s12517-017-3148-0

Besser H, Mokadem N, Redhaounia B, Hadji R, Hamad O, Hamed Y (2018) Groundwater mixing and geochemical assessment of low enthalpy resources in the geothermal field of Southwestern Tunisia. Euro-Mediterranean J Environ Integr 3:16. https://doi. org/10.1007/s41207-018-0055-Z

Bortolini L, Maucieri C, Borin M (2018) A tool for the evaluation of irrigation water qualityinthe arid and semi-arid regions. Agronomy 8:23. https://doi.org/10.3390/agronomy8020023

Carr MKV (2012) The water relations and irrigation requirements of the date palm (Phoenix Dactylifera L): a review. Exp Agric 49(01):91-113. https://doi.org/10.1017/s0014479712000993

CCME (2001) Canadian environmental quality guidelines for the protection of aquatic life. CCME water quality index: technical report, 1.0

Commissariat Régional du développement agricole CRDA (2018). Kebili en chiffres Rapport interne

Dewidar AZ, Ben Abdallah A, Al-Fuhaid Y, Essaf B (2015) Lysimeter based water requirements and crop coefcient of surface dripirrigated date palm in Saudi Arabia. Int Res J Agric Sci Soil Sci 5(7):173-183

Dhaouadi L, Ben Maachia S, Mkademi C, Oussama M, Daghari H (2015) Etude comparative des techniques d'irrigations sous palmier dattier dans les oasis de Deguache du Sud Tunisien. J New Sci Agric Biotechnol 18(3):658-667

Dhaouadi L, Boughdiri A, Daghari I, Slim S, Ben maachia S, Mkadmic C (2017) Localised irrigation performance in a date palm orchard in the oases of deguache. J New Sci Agric Biotechnol 42(1):2268-2277

Dhaouadi L, Besser H, Wassar F, Kharbout N, Ben Brahim N, Wahba M, Kang Y (2020) Comprehension of the kinetics of water in the soil from an irrigation test with a bubbler under date palm tree. J New Sci Agric Biotechnol 77(6):4533-4542

Dhaouadi L, Besser H, Wassar F, Kharbout N, Al-Omran A (2021) Assessment of natural resources in tunisian Oases: degradation of irrigation water quality and continued overexploitation of groundwater. Euro-Mediterranean J Environ Integr 6:36. https://doi.org/10.1007/s41207-020-00234-3

Duncan RC, Huck M (2000), USGA Green Section Record 38(5):14. <https://web.archive.org/web/20180423110053id_/http://gsrpdf. lib.msu.edu/ticpdf.py?file=/2000s/2000/000914.pdf

Edmunds WM, Guendouz AH, Mamou A, Shand P, Zouari K (2003) Groundwater evolution in the Continental Intercalaire Aquifer of southern Algeria andTunisia; Trace element and isotopic indicators. Appl Geochem 18:805e822. https://doi.org/10.1016/S08832927(02)00189-0

Edmunds WM, Shand P, Guendouz AH, Moulla AS, Mamou A, Zouari K (1997) Recharge characteristics and groundwater quality of the Grand Erg Oriental basin. British Geological Survery, London final report

FAO (2007) Date palm cultivation. Rome, Italy, pp 156

Gebremedhin B, Jaleta M, Hoekstra D (2009) Smallholders, institutional services, and commercial transformation in Ethiopia. Agricult Econ 40:773-787. https://doi.org/10.1111/j.1574-0862.2009. 00414.x

Ghazouani W, Marlet S (2009) Farmers' perceptions and engineering approach in the modernization of a community managed irrigation scheme A case study from an oasis of the Nefzawa (South of Tunisia). Irrig Drain 58(3):285-296. https://doi.org/ $10.1002 /$ ird. 528
Gibbs RJJS (1970) Mechanisms controlling world water chemistry. Science 170(3962):1088. https://doi.org/10.1126/science.170. 3962.1088

Haj-Amor Z, Tóth T, Ibrahimi K, Bouri S (2017) Effects of excessive irrigation of date palm on soil salinization, shallow groundwater properties, and water use in a Saharan oasis. Environ Earth Sci 76:590. https://doi.org/10.1007/s12665-017-6935-8

Hamed Y, Awad S, Ben Sâad A (2013) Nitrate contamination in groundwater in the Sidi Aïch-Gafsa oases region. Southern Tunisia. Environ. Earth Sci. 70:2335-2348. https://doi.org/10.1007/ s12665-013-2445-5

Hamed Y (2015) Les ressources hydriques en Tunisie et impact des changements climatiques. Editions europeennesuniversitaires, ISBN 978-9938-12-961-8.

Haritash AK, Gaur S, Garg S (2016) Assessment of water quality and suitability analysis of River Ganga in Rishikesh, India. Appl Water Sci 6:383-392. https://doi.org/10.1007/s13201-014-0235-1

Ishaku JM, Ahmed AS, Abubakar MA (2011) Assessment of groundwater quality using chemical indices and GIS mapping in Jada area, northeasternNigeria. Earth Sci Geotech Eng J 1(1):35-60

Kadri A, Van Ranst E (2002) Contraintes De La Production Oasienne Et Stratégies Pour Un Développement Durable: Cas Des Oasis De Nefzaoua (Sud Tunisien). Secheresse (montrouge) 13(1):5-12

Karbout N, Bol R, Brahimc N, Moussa M, Bousnina H (2019) Applying biochar from date palm waste residues to improve the organic matter, nutrient status and water retention in sandy oasis soils. J Res Environ Earth Sci 07(2019):203-209

Kumar P, Debele SE, Sahani J, Aragão L, Barisani F, Basu B et al (2020) Towards an operationalisation of nature-based solutions for natural hazards. Sci Total Environ 731:138855. https://doi. org/10.1016/j.scitotenv.2020.138855

Lacoue-Labarthe T, Reveillac E, Oberhänsli F, Teyssié J-L, Jeffree R et al (2011) Effects of ocean acidification on trace element accumulation in the early-life stages of squidLoligo vulgaris. Aquatic Toxicology, Elsevier 105:166-176. https://doi.org/10.1016/j.aquat ox.2011.05.021ff.ffhal-00785214

Lateef KH (2011) Evaluation of groundwater quality for drinking purpose for Tikrit and Samarra cities using water quality index. Eur J Sci Res 58(4):472-481

Longenecker DE, Lyerly PJ (1974) B-876 control of soluble salts in farming and gardening. Texas Agricultural Experiment Station, Texas A\&M University System, College Station, $36 \mathrm{p}$

Meireles ACM, Andrade EMD, Chaves LCG, Frischkorn H, Crisostomo LA (2010) A new proposal of the classification of irrigation water. Revista Ciência Agronômica 41(3):349-357. https://doi. org/10.1590/S1806-66902010000300005

Mekki A, Dhouib A, Sayadi S (2013) Review: effects of olive mill wastewater application on soil properties and plants growth. Int J Recycl Org Waste Agricult 2:15. https://doi.org/10.1186/ 2251-7715-2-15

Mezni M, Albouchi A, Bizid E, Hamza M (2002) Effet de la salinité des eaux d'irrigation sur lanutrition minérale chez trois de luzerne pérenne ( Medicago sativa L.). Agronomie 22:283-291

Mihoub A, Helimi S, Mokhtari S, Kharaz E, Koull N, Lakhdari K, Benzaoui T, Bougafa A, Laouisset M, Kherf Y, Halitim A (2015) Date palm (Phoenix dactylifera $\mathrm{L}$.) irrigation water requirements as afected by salinity in Oued Righ conditions, North Eastern Sahara, Algeria. Asian J Crop Sci 7(3):174-185

Mishra V, Aadhar S, Mahto SS (2021) Anthropogenic warming and intraseasonal summer monsoon variability amplify the risk of future flash droughts in India. Npj Clim Atmos Sci. https://doi. org/10.1038/s41612-020-00158-3

Mishra V, Smoliak BV, Lettenmaier DP, Wallace JM (2012) (2012) A prominent pattern of year-to-year variability in Indian Summer Monsoon Rainfall. Proc Natl Acad Sci USA 109:7213-7217 
Mohamed AMO, Maraqa M, Al Handhaly J (2005) Impact of land disposal of rejectbrine from desalination plants on soil and groundwater. Desalination 182(1-3):411-433. https://doi.org/10.1016/j. desal.2005.02.035

Nagaraju A, Sunil Kumar K, Thejaswi A (2014) Assessment of groundwater quality for irrigation: a case study from Bandalamottu lead mining area, Guntur District, Andhra Pradesh, South India. Appl Water Sci. https://doi.org/10.1007/s13201-014-0154-1

Nowak PJ (1992) Why farmers adopt production technology. J Soil Water Conserv 47(1):14-16

Omrani N (2011) Historical and contemporary perspectives of water culture in Tunisia. CIHEAM Options Méditerranéennes Série A Séminaires Méditerranéens 83(2008):75-84

Okoba BO, de Graaff J (2005) Farmers' knowledge and perceptions of soil erosion and conservation measures in the Central Highlands. Kenya Land Degrad Dev 16:475-487

Ramakrishnalah CR, Sadashivalah C, Ranganna G (2009) Assessment ofwater quality index for the groundwater in TumkurTaluk, Karnatakastate. India E-J Chem 6(2):523-530. https://doi.org/10. $1155 / 2009 / 757424$

Ramesh K, Elango L (2012) Groundwater quality and its suitability for domestic and agricultural use in Tondiar river basin, Tamil Nadu, India. Environ Monit Assess 184:3887-3899. https://doi.org/10. 1007/s10661-011-2231-3

Richards LA (1954) Diagnosis and improvement of saline and alkalisoils.USDA Hand book (60):160

Rodriguez C, Van Buynder P, Lugg R, Blair P, Devine B, Cook A, Weinstein P (2009) Indirect potable reuse: a sustainable water supply alternative. Int J Environ Res Public Health 6(3):1174209. https://doi.org/10.3390/ijerph6031174

Sghaier M (2010) Cas des Oasis en Tunisie, Etude de la gouvernance des ressources naturelles dans les oasis
Singh SP, Ma LQ, Tack FM, Verloo MG (2000) Trace metal leachability of land-disposed dredged sediments. J Environ Qual 29:1124-1132

Srivastava A et al (2012) Boronate affinity chromatography of cells and biomacromolecules using cryogel matrices. Enzyme Microb Technol 51(6-7):373-381

Stuyfzand PJ (1986) A new classification of groundwater and application to the coastal dune aquifer system in the Netherlands. In: Proceeding of the 9th salt water intrusion meeting, Delft, pp 641-655

US Salinity Laboratory (1954) Diagnosis and improvement of saline andalkaline soils. U.S. Dept. of Agriculture HandBook, 60: 160p

Vanclay F, Lawrence G (1994) Farmer rationality and the adoption of environmentally sound practices; a critic of the assumptions of traditional agricultural extension. J Agric Edu Ext 1:1-5

Van Mele P, Vayssieres J-F, Adandonon A, Sinzogan A (2009) Ant cues affect the oviposition behaviour of fruit flies (Diptera: Tephritidae) in Africa. Physiol Entomol 34:256-261. https://doi.org/ 10.1111/j.1365-3032.2009.00685.x

Zaid A, de Wet PF (2002) Botanical and systematic description of the date palm. In: Zaid A, Arias-Jiménez EJ (eds) Date palm cultivation. FAO Plant Production and Protection paper 156, Rev. 1. Rome, Italy

Zhang H, Richardson PA, Belayneh BE, Ristvey A, Lea-Cox J, Copes WE, Moorman GW, Hong C (2015) Characterization of water quality in stratified nursery recycling irrigation reservoirs. Agric Water Manag 160:76-83

Publisher's Note Springer Nature remains neutral with regard to jurisdictional claims in published maps and institutional affiliations. 